\title{
Aristotle and the People: Vernacular Philosophy in Renaissance Italy ${ }^{1}$
}

\author{
Marco Sgarbi \\ Università Ca’ Foscari
}

The essay focuses on vernacular Aristotelianism in Renaissance Italy, which began to gain currency in the 1540s, just as the vernacular was beginning to establish itself as a language of culture and the Counter-Reformation was getting underway. With over three hundred printed and manuscript works, the statistics of this phenomenon are impressive. Even so, the vulgarization of Aristotle in the Italian Renaissance has never received the scholarly attention it deserves. The paper examines (1) the identity of the recipients of Aristotle's vulgarizations, (2) the meaning of the process of vulgarization, and (3) the conception of knowledge that such writings brought to the culture of the Cinquecento. The purpose is to show that (1) vernacular renderings of Aristotle's works were aimed at the "people," including "idiots" (men lacking culture or knowledge of Latin), "simpletons," "ignorants," and "illiterates" as well as princes, men of letters, women, and children, (2) vulgarization was not simply a matter of disseminating, simplifying, and trivializing knowledge, and (3) vulgarization upheld the notion of widespread knowledge.

L'article se concentre sur l'aristotélisme vernaculaire en Italie de la Renaissance, qui s'est grandement développé au cours des années 1540, au moment où la langue vernaculaire s'est imposée comme langue de culture alors que la Contre-Réforme débutait. Avec plus que quatre cent ceuvres imprimées ou manuscrites, les chiffres de ce phénomène sont impressionants. Malgré tout, la vulgarisation d'Aristote pendant la Renaissance italienne n’a jamais reçu l'attention savante qu'elle mérite. L'article examine 1) l'identité des destinataires des vulgarisations d'Aristote 2) le sens du processus de vulgarisation, et 3) la conception de la connaissance que représentent ces textes dans la culture de Cinquecento. L'objectif est de démontrer que les traductions vernaculaires des ouvres d'Aristote s'adressaient au peuple, y compris les "simples" (les hommes sans culture ni connaissance du latin), les nigauds, les ignares, et les illettrés ainsi que les princes, les hommes de lettres, les femmes, et les enfants, 2) la vulgarisation nétait pas une affaire simple de dissémination, qui simplifie et fait circuler le savoir, et 3) la vulgarisation sert l'ambition d'une circulation des savoirs.

1. I gratefully acknowledge the help and suggestions of Alessio Cotugno, Gigliola Fragnito, and Laura Refe during the writing of this paper. This research has been possible thanks to the ERC Starting Grant 2013, n. 335949, "Aristotle in the Italian Vernacular: Rethinking Renaissance and Early-Modern Intellectual History (c. 1400-c. 1650)," http://aristotleinthevernacular.org. 


\section{Vernacular Aristotelianism in Renaissance Italy}

It is customary in historiographical and philosophical research to disregard vernacular philosophy in Renaissance Italy. Against the vast output of texts written in Latin, the idea of philosophy as a subject of debate in the vernacular at a time when literacy rates were still so low has always appeared to be of marginal importance. ${ }^{2}$ As the language in which philosophical doctrines were generally disseminated, Latin was the necessary condition of any philosophical discussion, while philosophy itself was mostly of interest only to university professors, intellectuals, and clerics for whom being conversant with the Latin language was a part of the profession. Very few intellectuals, let alone philosophers, produced vernacular writings in this period, ${ }^{3}$ and the first vernacular works of philosophy, unsurprisingly, were devoted to themes that were of particular interest to Renaissance readers, namely rhetoric, politics, ethics, and economics. ${ }^{4}$ Equally unsurprising is the fact that the first philosophical texts in the vernacular were translations of classic works by Plato and Aristotle. Such translations reflected a strictly humanistic interest in Greek authors while providing a direct link to the two most important philosophical currents in Western culture alongside Christian thought.

Although the entire corpus of Plato's works was rediscovered in the latter half of the Quattrocento, Plato was vulgarized less extensively than Aristotle, whose works offered a more systematic treatment of the full range of philosophical disciplines. Interest in the Stagirite began to revive between the end of the twelfth and the start of the thirteenth centuries, and just as he came to be known as the Philosopher, his philosophy came to be known as the Philosophy.

2. For literacy statistics in the Cinquecento, but only in reference to Venice, see Paul Grendler, Schooling in Renaissance Italy: Literacy and Learning, 1300-1600 (Baltimore and London: Johns Hopkins University Press, 1991), 42-47.

3. On humanism as a period of unrest in the production of vernacular writings, see Mirko Tavoni, Storia della lingua italiana. Il Quattrocento (Bologna: il Mulino, 1992), 65. See also Letizia Panizza, "The Quattrocento," in The Cambridge History of Italian Literature, ed. Peter Brand and Lino Pertile (Cambridge: Cambridge University Press, 1999), 152-54. On vernacular philosophy in the fifteenth century, see James Hankins, "Humanism in the Vernacular: The Case of Leonardo Bruni," in Humanism and Creativity in the Renaissance: Essays in Honor of Ronald G. Witt, ed. Christopher S. Celenza and Kenneth Gouwens (Leiden: Brill, 2006), 11-31.

4. On this point, see Luca Bianchi, "Per una storia dell'aristotelismo volgare nel Rinascimento: problemi e prospettive di ricerca," Bruniana \& Campanelliana 15 (2009): 367-85. 
But humanism, with its emphasis on the philological reconstruction of Aristotle and his commentators, made the vulgarization of the Philosopher's works a laborious process in which his original Greek words had to be recovered before any reconstruction of his thought could begin.

The so-called "vernacular Aristotle" began to gain currency in the 1540s, just as the vernacular was establishing itself as a language of culture and the Counter-Reformation was getting underway. ${ }^{5}$ The setting for this new phenomenon was far removed from the traditional Aristotelian strongholds of the universities and the monasteries: namely, the academies and courts, but also workshops and printing houses; places, in other words, beyond the walls of the universities, where philosophy was still taught in Latin. With over three hundred printed and manuscript works, the statistics are indeed impressive. Yet, even so, the vulgarization of Aristotle in the Italian Renaissance has never received the attention it deserves from the experts.

It is only recently, thanks in particular to the tireless efforts of David Lines and Luca Bianchi, that light has begun to be shed on this area. ${ }^{6}$ Bianchi gives an accurate account of the underlying reasons for this neglect. ${ }^{7}$ First, popularization has always been seen as the primary purpose of vernacular writings, a view that has led to the assumption that vernacular writings are lacking in originality and theoretical depth. Second, historians have always overplayed the distinction between philosophers who were serious and committed professionals and those who were mere popularizers with scant doctrinal knowledge. The former generally wrote in Latin and deserved to be studied, whereas the latter were mere footnotes to the wider philosophical debate in the Renaissance. A third, related reason is that the only systematic study so far available on this topic, by Wiktor Wasik, is based on the false assumption that "vernacular" is

5. It was also at this time that the Bible began to be widely vulgarized; see Gigliola Fragnito, La Bibbia al rogo. La censura ecclesiastica e i volgarizzamenti della Scrittura (1471-1605) (Bologna: Il Mulino, 1997), 39.

6. For an exhaustive overview on studies on vernacular Aristotelianism, see David A. Lines, "Beyond Latin in Renaissance Philosophy: A Plea for New Critical Perspectives," Intellectual History Review 4 (2015), 1-17; David A. Lines, "Introduzione," in "Aristotele fatto volgare": Tradizione aristotelica e cultura volgare nel Rinascimento, ed. D. A. Lines and E. Refini (Pisa: ETS, 2015), 1-10.

7. Bianchi lists these reasons in Bianchi, "Per una storia dell'aristotelismo volgare nel Rinascimento," 367-85. 
synonymous with "popular," an assumption that has led research to focus more on the dissemination of the works than on their significance within the context in which they were produced. A fourth, eminently practical reason has been the lack of inventories of vernacular philosophical works from this period, a lack that the Warwick-based project led by David Lines and Simon Gilson has done much to redress, thereby making it possible at least to fill in some of the gaps in the research. ${ }^{9}$

Many questions remain open, however, one of which is the peculiar similarity between certain Reformation ideals and the views of intellectuals involved in translating Aristotle into the vernacular: at a time when the reformist movement wanted to open Christian doctrine up to the entire population, also by means of vernacular renderings of biblical writings, intellectuals were resorting to vernacular renderings of Aristotle in order to disseminate Aristotelian doctrines among as wide a swathe of the population as possible. In both cases, opening up access to knowledge was seen as the most direct means of individual emancipation from authority and cultural renewal.

It is not my intention here to examine Protestant ideas concerning the adoption of the vernacular ${ }^{10}$ but rather to inquire into a common concept of vulgarizing certain aspects of knowledge that some intellectuals in Italy shared with reformist movements during a religious crisis that deeply affected sixteenth-century Italian culture. For the purposes of my investigation, and in order to show that the connection between Aristotle's vulgarizers and reformist movements is not merely whimsical but is based on solid grounds, I wish to

8. Wiktor Wasik, "Laristotélisme populaire comme fragment de la Renaissance," Revue d'Histoire de la Philosophie et d'Histoire Générale de la Civilisation 9 (1935): 33-66.

9. The project was titled Vernacular Aristotelianism in Renaissance Italy, c. 1400-c. 1650. More details can be found on the website: http://warwick.ac.uk/vernaculararistotelianismproject. Jill Kraye, Luca Bianchi, Eugenio Refini, and Grace Allen also contributed to this project.

10. It is important also to mention here certain notions advanced by Martin Luther in his letter On Translating for their striking resemblance to some of the ideas upheld by Aristotle's vulgarizers, especially where he asserts that in order to be understood by the people we must write and speak not in Latin or Greek but in the language of the housewives, the children, and the common people: "We do not have to ask the literal Latin how we are to speak German, as these donkeys do. Rather we must ask the mother in the home, the children on the street, the common man in the marketplace. We must be guided by their language, by the way they speak, and do our translating accordingly. Then they will understand it and recognize that we are speaking German to them." Martin Luther, Werke, vol. 2 (Weimar: Böhlaus, 1909), 640. 
focus on (1) the identity of the recipients of Aristotle's vulgarizations, (2) the meaning of the process of vulgarization, and (3) the conception of knowledge that such writings brought into the culture of the Cinquecento. This will allow us to see that (1) vernacular renderings of Aristotle's works were aimed at what we shall call the "people," (2) vulgarization was not just a simple matter of disseminating, simplifying, and trivializing knowledge, and (3) vulgarization upheld the notion of the openness of knowledge. Each of these themes will be treated in a separate paragraph. ${ }^{11}$

\section{The people}

Before going on to explain what is meant by the people being the recipients of Aristotelian vulgarizations, it is worthwhile first to introduce the distinction suggested by Natalie Zemon Davis between "audience" and "public"; in other words, between the number of actual readers founded on the basis of library catalogues and other objective sources, and the target readership imagined by the authors when writing their books. ${ }^{12}$ It is a useful distinction to make, because we can interpret the phenomenon of Aristotelian vulgarizations differently according to whether we are looking at the public or the audience.

In "Volgarizzare Aristotele: per chi?" Luca Bianchi asks the crucial question of who the "real" recipients of Aristotelian vulgarizations in the Italian Renaissance were, therefore focusing primarily on their audience. He concludes that programmatic statements contained in prefaces and dedicatory letters are not reliable indicators, as such statements must be read in the context of the editorial considerations that went into the making of the texts. The physiognomy of the recipients is determined not only by the language that is used

11. It seems fitting, here, to comment on my own treatment of the texts. For citations from works published between the fifteenth and sixteenth centuries I follow the numbering used by the authors themselves. My general rule has been to preserve original spelling and punctuation except where the best editions happen to be in modernized form; in the former, I have introduced minor changes as the sentence requires. When transcribing Italian vernacular, I have expanded all contractions, while dropping diphthongs and omitting diacritical marks. When quoting I very occasionally add punctuation to make clearer what I take to be the sense of difficult passages. For citations from secondary sources, I have used the latest editions in their original languages.

12. Natalie Zemon Davis, Society and Culture in Early Modern France: Eight Essays (Stanford: Stanford University Press, 1975), 192-93. 
but also by the body of background knowledge that is assumed and the range of competences that are deemed to be transmissible. ${ }^{13}$ Vernacular texts, as Bianchi has correctly pointed out, can contain references to ancient authors or commentators, complex doctrines, sometimes also long citations in Greek and Latin, or philological disquisitions on the authenticity of the sources involving textual and paratextual skills normally associated with restricted groups of people, ${ }^{14}$ suggesting a socially elevated or even aristocratic audience ${ }^{15}$ capable of "handling matters of exegesis and philosophy of considerable difficulty." 16

My approach, on the other hand, is to look at the question of who philosophical and scientific writings in the Cinquecento were vulgarized for from the point of view of the public rather than the audience. The intended "public" of certain works is the key element in intellectual history because it reveals the intentions and aims of intellectuals at a given time. The audience can testify only to the effectiveness of the attempted vulgarization, a matter that is beyond the purview of the author. The fact that a work does not always measure up to the intentions and needs of vulgarization may be determined by a range of factors such as the complexity of the topic, the absence of a specific language, or the authors' inability to fulfil their own purposes. A vulgarizer may set out to write the easiest and most accessible book possible and fail in any number of ways. The vulgarizers themselves were well aware of the difficulties they faced, as evidenced, for instance, by Ludovico Castelvetro, a key figure in the reformist movement in the Italian Cinquecento. ${ }^{17}$ In his Poetica d'Aristotile vulgarizzata et sposta, rightly selected by Bianchi as an example of an erudite vernacular text requiring knowledge of classical languages and literature, ${ }^{18}$ Castelvetro is aware of having vulgarized "perhaps with greater ardour of spirit than felicity

13. Luca Bianchi, "Volgarizzare Aristotele: per chi?," Freiburger Zeitschrift für Philosophie und Theologie 59 (2012), 494.

14. Bianchi, "Volgarizzare Aristotele," 493.

15. Bianchi, "Volgarizzare Aristotele," 486.

16. Bianchi, "Volgarizzare Aristotele," 493.

17. On Castelvetro's heterodoxy, see his essays in Lodovico Castelvetro. Filologia e ascesi, ed. Roberto Gigliucci (Rome: Bulzoni, 2007) and in Ludovico Castelvetro: letterati e grammatici nella crisi religiosa del Cinquecento, ed. Massimo Firpo and Guido Mongini (Florence: Olschki, 2008).

18. Bianchi, "Volgarizzare Aristotele," 493. As we shall see later in the paragraph, Castelvetro wrote not for the common people but for poets and literary critics who had at least some grounding in Greek and Latin literature. 
of result." ${ }^{19}$ In a rare moment of modesty, Castelvetro acknowledges that despite being moved by a genuine desire to vulgarize and clarify as much as possible the content of Aristotle's poetics, the outcome is not what he had hoped for. Another notable case is Alessandro Piccolomini's In mechanicas quaestiones Aristotelis paraphrasis paulo quidem plenior (1547), vulgarized in 1582 by Oreste Vannocci Biringucci with the title Parafrasi di Monsignor Alessandro Piccolomini [...] sopra le Mechaniche d'Aristotele. Biringucci maintained that in order to "satisfy his just and ardent desire to benefit all, without prejudice of any kind, easily and happily, he [Piccolomini] set about adorning our language with every kind of science," and above all

regretted having written in Latin, alongside certain other fine works, during his best years, and among his studies also this paraphrase of the Mechaniche d'Aristotele, because he saw that since it was in Latin it was not accessible to those who could have made the best use of it [that is] engineers and architects. ${ }^{20}$

According to Biringucci, therefore, Piccolomini believes it was a mistake to write in Latin rather than the vernacular, because the intended recipients who should have made use of the text were unable to read it. It is a significant observation because it shows how intellectuals sometimes fell short of their stated intentions despite their democratizing zeal: it was most likely not infrequent for the intended public of Latin or vernacular texts with complex commentaries to be much wider than the public they actually reached.

The failure of a single project, however, does not detract from the intentions such works conveyed-intentions that played a significant role in shaping the mindset of the time. This is why I believe it is important to focus also on direct evidence and the voice of the authors. ${ }^{21}$

The sources are divided here by discipline, and each group brings together authors from different periods using different linguistic registers: 


\section{a. Politics and ethics}

[...] having laboured [...] to reduce to the form of paraphrase all eight books of the Politics [...] adding particular commentary to each book, as well as various annotations and pertinent questions to help in the overall understanding of the text, which it has been greatly pleasing to bring to this point, as it has allowed me to see clearly how great a benefit the civil discourses written by Aristotle are to men, who are operating manuals of government, for setting them up, ordering them, and maintaining them. ${ }^{22}$

Since no small benefit is derived by men from the knowledge of government and the running of cities, in these past days from Greek sources I have drawn Italic streams, the eight books of the Republic, which they call Politics. ${ }^{23}$

But since the doctrine of Aristotle is wrapped in considerations of such depth that a great deal of study and attentive research is required of any who wish to master it, it has been my intention to ease the way of this science, reducing it so to speak to the substance, and explaining it clearly and succinctly, so that thus exposed to greater ease of understanding it shall reveal of its own the errors that have entered into the art of politics from the world [...] having left aside the digressions, the responses and the lengthy disputations [...] I have captured the sentiment of Aristotele [...] so that, if I am not mistaken, in brevity no greater clarity could be wished for, nor could such breadth of material be reduced to greater brevity.

22. Antonio Scaino, La politica di Aristotele ridotta in modo di Parafrasi (Rome: Case del Popolo Romano, 1578), preface: “[...] havend'io, conforme alla fatica dell'Ethica, ridotto sotto forma di Parafrasi tutti gli otto libri della politica $[\ldots]$ con particolari argomenti sopra ciascun libro, et con l'aggionta insieme di varie annotazioni, et dubbi molto opportuni, da me posti insieme per maggiore intelligenza di tutta l'opra: la quale mi sono ancho compiaciuto pur assai d'haver condotta a questo fine, per havere manifestamente conosciuto, quanto grande utile possino arrecare a gli huomini, che sono manuali operatori de governi, et per instituirgli, \& per assettargli, \& per conservargli, questi civili discorsi composti da Aristotele."

23. Antonio Brucioli, Gli otto libri della republica (Venice: Brucioli, 1547), dedication: "Perché non piccola utilità aporta a gli huomini la cognitione de governi, \& reggimenti delle città, a questi passati giorni, da fonti greci tirai a rivi italici, gli otto libri della Republica, che chiamano Politica." 
And in so doing I believe I have made a useful and worthy contribution to Princes \& men of republic \& court, for whom it shall serve as a reminder of civil discipline, seeing as they are distracted by their work and responsibilities and cannot normally attend to such studies $[\ldots]{ }^{24}$

[...] having recently received the works of the singular Philosopher Aristotle, the Secret of secrets, and the Ethics, of pleasing and useful subjects to all kinds of men; and considering how much benefit they bring to all, I dedicated myself for the common good to translating them into a plain and common language. ${ }^{25}$

Having witnessed [...] since my early years many Princes \& other noble individuals pass almost indifferently through life without letters and without any adornment of praiseworthy customs, and feeling troubled by this, I always had this thought that if they had devoted themselves to reading and understanding what Aristotle left us in his books on Ethics, the love of good virtues would easily have been ignited in their souls, as well as the desire to acquire them. Thinking then that the manner of expression of that philosopher is not suitable for idiot men, and therefore

24. Panfilo Persico, Della filosofia morale \& politica d’Aristotele (Venice: Ciotti, 1617), b3: "Ma perché la dottrina d'Aristotele è involta in considerazioni così profonde, che grande studio, \& attenzione ricerca, da chi se ne voglia render capace, perciò è stato mio consiglio d'agevolar la via a questa scienza, con ridurla quasi in sostanza, e spiegarla con chiarezza \& brevità, accioch'esposta a più facil cognitione faccia per se stessa più chiari gli errori, che sono seguiti dal mondo nell'arte politica [...] lasciate le digressioni, le repliche, \& le disputationi prolisse [...] ho raccolto il sentimento d'Aristotele [...] in modo che, se non m’inganno, nella brevità non si possa desiderar più chiarezza, ne l'ampiezza di materie cos' gravi ristrigner in maggior brevità. In che ho stimato di far opra grata, \& profittevole à Principi, \& huomini di republica, \& di corte, a quali potrà servir per memoriale della disciplina civile, poiché distratti nelle occupationi, \& uffici della vita non possono applicarsi ordinatamente a questi studi [...].”

25. Giovanni Manenti, Col nome de Dio, Il segreto de Segreti, le Moralità, \& la Phisionomia d'Aristotele (Venice: Tacuino, 1538), Aiiv: “[...] essendomi ultimamente pervenuto à le mani de l'opere del singolar Philosopho Aristotile, Il segreto de segreti, \& le moralità, di soggetto dilettivoli, \& utilissimo a ogni sorte d'huomini; \& considerando il giovamento che possi esser ad ognuno, mi son messo per utilità comune a traslatarle in lengua plana e volgare." 
that it would be necessary to make it easier in our language so that every person, however simple, could receive its message. ${ }^{26}$

[...] it so happens that this eminent and great philosopher [Aristotle], being overly subtle in his treatment of the sciences, is for this reason so obscure to many as not to be fully understood. [...] Hence wishing greatly, while His Holiness [Pope Julius III] is intent on correcting the world and leading it on the right path of religion, that likewise Aristotle should lead us on the path of good conduct more easily than in the past, I have endeavoured with all my strength to make his teaching clear in a new way, so that in this century of ours every one of us can find the right path each in his own way. And I thought that it should be done first by transposing his science into a more common and accessible language, which Greek and Latin are not, and then ironing out the many difficulties he artificiously filled his writings with. ${ }^{27}$

I am inspired to act for the benefit of the world (because we are all born to give benefit) [...] Having therefore diligently inquired, and finally seen that the things Aristotle writes in all his books are by their nature even very straightforward, but are made to seem obscure because of the

26. Galeazzo Florimonte, Sopra l'Ethica d'Aristotile (Venice: Nicolini, 1567), dedication: "Veggendo io $[\ldots]$ infin dalla mia gioventù molti Principi, $\&$ altre persone nobili, quasi indifferentemente menarne senza lettere la vita loro, \& senza ornamento alcuno di lodevoli costumi, \& di ciò dolendomi insieme; hebbi sempre questo pensiero, che quando essi si fossero dilettati di leggere, \& d'intendere quello, che ci lasciò scritto Aristotile ne suoi libri dell'Ethica, si sarebbe potuto agevolmente destare ne gli animi loro lamore delle belle virtù, \& il desiderio dellacquistarle. Considerando poi, che la maniera del parlare di quel filosofo non è atta ad essere intesa da gli huomini idioti, \& che perciò sarebbe stato bisogno spianarlo talmente nella lingua nostra, che ogni persona, per semplice che fosse, n'havesse potuto haver notitia."

27. Felice Figliucci, Della filosofia morale libri dieci (Rome: Valgrisi, 1551), dedication: “[...] questo dignissimo, e gran filosofo [Aristotele], nel trattare troppo sottilmente le scienze è tanto in tal guisa oscuro che da molti per avventura non è pienamente inteso [...] Per tanto desiderando io sommamente, che mentre che la Santità V. [Papa Giulio III] è tutta intenta a correggere il mondo, \& indirizzarlo ne la vera strade de la religione, parimente Aristotile con più facil modo che per l'addietro non ha fatto, a lacquisto de buon costumi ci guidasse, ho cercato con ogni mio sforzo, in nuova maniera renderlo chiaro, acciocché in questo nostro seculo ciascuno per diverse vie si indirizzasse al ben fare. E mi avvisai dovermi venir fatto, prima trasportando la sua scienza in una lingua più comune, \& agevole che la greca, o la latina non è, di poi sciogliendo molte difficultà, de le quali egli ad arte volse esser ripieno." 
difficulty and succinctness of their treatment, I have endeavoured to make them as clear as it was possible for me to do so [...] rendering them in this language of ours, and expanding considerably where he was constricted, and brief [...] for the same reason I have avoided raising the style too high [...] but have tried instead to use middling, appropriate, and clear words that are accessible to someone whose only interest is to teach and is far removed from ostentation and superfluity of words. ${ }^{28}$

I sought to devote a few hours of the night [...] after a brief rest, to the study of moral philosophy, a fitting study, \& and one that is perhaps necessary for anyone who governs people \& cities, as you justly \& piously do. [...] And this is a brief introduction to the Ethics of Aristotle, already attempted a while ago in a scholarly and useful manner by Jacques Lefèvre d'Étaples [...] it seemed to me not inappropriate to translate the introduction also of this work into the vernacular [...] Nor will I dwell too long on revealing to you and showing you the usefulness of this introduction [...] I will say only that reading this work alone, and observing it, every man can become an excellent \& perfect moral philosopher. ${ }^{29}$

With this translation [...] I will give considerable benefit to those who do not know all those languages which have conveyed to us so many

\footnotetext{
28. Figliucci, letter to the readers: "[...] io ho in animo di fare in giovamento del mondo (perché tutti a giovare siamo nati) [...] Havendo io adunque diligentemente considerato, e veduto finalmente che le cose che scrive Aristotile in tutti li suoi libri, per natura loro sono facili pur assai e che solo paiono oscure per la difficultà e brevità con la quale egli ha trattate; mi sono sforzato di renderle chiare quanto per me sè potuto $[\ldots]$ mettendole in questa nostra lingua, et allargandomi assai, dove egli è stato stretto, e breve [...] per la medesima cagione non ho cercato di inalzarmi con lo stile troppo altamente [...] ma ho voluto usar parole mediocri, propie, e chiare, convenienti ad uno che solo desidera insegnare e che sia lontano da ogni vano ornamento e superfluità di parole."

29. Giulio Landi, Le attioni morali (Venice: Giolito, 1584), 1-2, 12: “[...] io mi sforzai di porre qualc'hora della notte $[\ldots]$ dopo un breve sonno, nello studio della Filosofia morale, studio invero convenevole, \& forse anco necessario a chiunque governa popoli, \& cittadi, si come voi giustamente \& santamente fate. [...] E ciò sia una breve introduttione nell'Ethica d'Aristotele, già buon tempo fa da Iacopo Fabro dottamente, \& utilmente composta [...] parvemi non essere disconvenevole l'introduttione anco d'essa rendere volgare $[\ldots]$ Ne mi estenderò molto in aprirvi, \& mostrarvi l'utilità di questa introduttione [...] Dirovvi solamente, che questa sola opera leggendo, \& osservando, può ciascuno huomo divenire eccellente \& perfetto filosofo morale."
} 
noble sciences; ignorance of which deprives them of the knowledge of such beneficial things. ${ }^{30}$

But since this custom of giving Baptism gifts is not the same throughout Italy [...] according to the customs of our City of Siena it falls to me to give your child a gift, I debated in my mind for a long time what worthy Gem I could present to him. And as everything seemed unworthy to me, I finally decided that I could present to him no joy of greater worth than an institution for his entire life, such as could be drawn from the depths of Aristotle and Plato: so that he would find himself guided from the cradle through all the stages of his life according to the moral code, finally reaching the utmost happiness that is appropriate to man as man. Nor was I discouraged from my purpose by the thought that it might be a superfluous task, since he has you as his mother to instruct him very satisfactorily: no small benefit, it seemed to me, would he derive, as your knowledge demonstrates, from his becoming acquainted with these great philosophers. ${ }^{31}$

\section{b. Rhetoric and poetics}

Last year, most illustrious Prince [Cosimo De' Medici], having set myself to doing something that would please Your Excellency and at the same time would prove beneficial if not to all men, then at least the majority

30. Giulio Ballino, La morale filosofia (Venice: Valvassori, 1564), 10: "Con questa tradottione [...] gioverò appresso non poco a coloro, i quali non intendono tutte quelle lingue che nodrite ci hanno tante nobili scienze; la quale ignoranza li priva della cognition di così salutevoli cose."

31. Alessandro Piccolomini, De la institutione di tutta la vita de l'homo (Venice: Scoto, 1545), 5r: "Ma perché questa usanza dei doni del Battesimo in ogni luogho d'Italia non è conforme [...] secondo lusanza de la Città nostra di Siena: a me tocca di qualche presente il figlio vostro adornare più tempo rivolsi ne la mente fra me medesimo, qual degna Gemma donar gli potesse. Et ogni cosa indegna parendomi, mi risolvei finalmente, che più ricca gioia, ritrovar per lui non potevo, che un'institutione di tutta la vita sua, laqual si tresse da le viscere d'Aristotele e di Platone: ond'egli fin da le fascie di età in età prendendo norma al vivere suo, finalmente a la somma felicità, che a l'hom si conviene come homo, condotto si ritrovasse. Ne a quest'impresa mi sbigottiva il pensar che fusse superfluo di questo fare, havend'egli per madre voi che bastantissimamente instituir lo potrete: però che non poco giovamento consideravo io, che dovesse essergli che quello istesso, che ne l'esempio di voi sia per cognoscere, vegha conforme al giudicio di si gran Filosofi." 
of them, as far as it was in power to do so, I decided to render in our Florentine language the Rhetoric of the great Aristotle [...] A translation, most illustrious Prince, which may serve those who, not reading Greek and who do not disdain to read in the vernacular, will not be concerned with knowing in exquisite detail all that is required to understand this Art, but will be content to know the subject-matter in an approximate manner. ${ }^{32}$

[...] without wishing to ignore the words of others, especially those that appeared to me not to have been uttered inappropriately [by others], and without stinting on the authority of other writers in order to convey the meaning of the histories and the fables, and the other obscure things written by Aristotle, I did what I deemed necessary, perhaps with greater ardour of spirit than felicity of result, to represent the poetic art not only by showing and opening up that which has been written in these few pages by that supreme philosopher, but also what should or could have been written for the benefit of those who desire to know how properly to compose poems and rightly to judge whether their compositions have the right attributes or not. ${ }^{33}$

32. Bernardo Segni, Rettorica et poetica d'Aristotile (Venice: Imperatore, 1551), 2r, 4r: "Havendomi Principe Illustrissimo [Cosimo De’ Medici] nell'anno passato posto dinanzi agli occhi per oggetto di far qualche cosa, che piacesse a V. Ecc. et insieme che fusse per giovare se non a tutti, almeno a quella più parte degli huomini, che per me si potesse: mi venne in animo di mettere in questa nostra lingua Fiorentina la Rettorica del grande Aristotile [...] La qual'traduttione Principe Illustrissimo forse potrà servire a coloro, i quali non sappiendo la Greca lingua, \& in questa non si disdegnando di leggere, non si cureranno di saper così squisitamente tutto ciò, che s'appartiene per intender questa Arte, ma che basterà loro di conoscer questa materia alquanto più grossolanamente."

33. Castelvetro, Poetica d'Aristotele volgarizzata et sposta, Aiii: “[...] io senza tralasciare punto la dichiarazione delle parole, \& specialmente di quelle che non mi sono parute essere state sconvenevolmente dagli altri dichiarate, \& senza risparmiare l'autorità degli altri scrittori per fare intendere l'historie \& le favole, \& l'altre cose oscure scritte da Aristotele quanto ho giudicato far bisogno ho tentato, \& forse con più ardore d'animo che con felicità d'effetto, di far manifesta l'arte poetica non solamente mostrando \& aprendo quello che è stato lasciato scritto in queste poche carte da quel sommo philosopho, ma quello anchora che doveva o poteva essere scritto per utilità piena di coloro che volessero sapere come si debba fare a comporre bene poemi, \& a giudicare dirittamente se i composti habbiano quello che deono havere o no." 


\section{c. Logic}

[...] for the sole desire of benefitting the many that I know who have excellent minds, well suited to doing philosophy, and not knowing any other language than their mother tongue, Italian, so as not to waste what is left to them of their good years in foreign languages, so wrapped in ignorance are they, that I decided some years ago to treat matters of philosophy, not only in an orderly and accessible manner, but also in our pure Italian language. ${ }^{34}$

Women likewise, in the virtue in which Aristotle maintains that the happy state of the city resides, it not being the custom in Italy to make them learn any language other than what they learn from their wet-nurses, thus remain deprived and stripped through no fault of their own of those habits which could make them happy: nor can they through reading learn how powerful are the virtues which serve them so well, nor through which operations, exercises, and offices they can perfect themselves, every good news being closed in the womb of Philosophy. ${ }^{35}$

Since [...] the doctrine of Aristotle (not to mention his other parts) is a mirror and a law of civil living, and likewise order and government of affairs of state, I deemed it to be extremely useful to see it in our vernacular

34. Alessandro Piccolomini, L'instrumento della filosofia (Rome: Valgrisi, 1551), aiir-v: "per solo desiderio di giovare a molti che io conosco d'intelletto buonissimo, et atto a filosofare, i quali non sapendo altra lingua che la italiana lor materna, per non cusmare intor lingue stranie, quel che gli avanza de i buoni anni loro, involti si vivano ne l'ignorantia, mi lasciai cader' in animo alquanti anni sono di trattare scrivendo le cose di Filosofia, non solo con ordine pieno d'agevolezza [...] ma con lingua pura Italiana nostra."

35. Alessandro Piccolomini, L'instrumento della filosofia (Rome: Valgrisi, 1551), aiiiiv: "Le donne parimente, ne la virtù de le quali vuole Aristotele che il mezo del felice stato de le città risegga, non essendo costume in Italia di far loro apprender' altra lingua, che quella che dà le nutrici imparano; restan per questo prive, et ignude senza lor colpa di quelli habiti, che far le potrien felici: né possan leggendo imparare di quanta forza sieno le virtù che lor convengano, et con quali operazioni, esercitazioni, et offitij si possin perfette rendere: essendo ogni buona notitia nel ventre chiusa de la Filosofia." 
language as well as reduced to a practical brevity, so that it could be accessible and understood by everyone. ${ }^{36}$

\section{d. Psychology}

[...] all men of letters that are good by nature, because they seek to communicate the gifts that God granted them, will comfort each person in such a way that a person will seek the condition and the strength to become virtuous; and if they see a woodsman, they will inspire him at least to turn to mathematics, if not other things [...] and so they will encourage an apothecary to take up medicine: and ultimately each person to try to learn the things they think will be useful and honourable in some way. ${ }^{37}$

And it is my purpose to write this work in our vernacular, so that those who are by nature gifted with excellent discourse and fine intellect, but know neither Latin nor Greek, may understand this science, which until now we might say has been buried to them. ${ }^{38}$

36. Ludovico Dolce, Somma della filosofia d'Aristotele, e prima della dialettica (Venice: Sessa, 1565), "2: "Essendo, [...] la dottrina di Aristotele (per tacer le altre sue parti) specchio e regola del viver Civile, e parimente ordine e governo de le cose pubbliche, ho giudicato sempre cosa di grandissimo profitto, che ella si potesse vedere nella nostra volgar lingua, e ridotta in una convenevole brevità, accio che la medesima fosse agevole ad essere appresa da tutti."

37. Giovan Battista Gelli, Opere (Torino: UTET, 1976), 175-76: “[...] tutti i letterati che sono di natura buoni, cercando di communicare, quei beni che ha dato loro Iddio, conforteranno ciascuno in quel modo che ricercherà lo stato e 'l potere di colui, a darsi a le virtù; e se vedranno un legnaiolo, lo inanimiranno almanco a le cose di matematica, se non ad altro $[\ldots]$ e così conforteranno uno speziale a studiare medicina: e ciascheduno finalmente a cercare di imparare quelle cose che penseranno dovergli essere in qualche parte utili e onorevoli."

38. Francesco Venier, I discorsi sopra i tre libri dell'anima d'Aristotele (Venice: Arrivabene, 1555), 1v: "Et questa opera io intendo di scrivere in lingua nostra volgare; acciò che quelli, che sono dotati dalla Natura di ottimo discorso, \& d'acutissimo intelletto, \& non posseggono né la lingua Latina, né la Greca, possano intendere questa scienza, che in fino a qui a loro si può dir che sia stata sepolta." 
Men of prudence and judiciousness must endeavour to make idiot and vulgar men as little so as possible, and there is no other way to do this than to teach them first the virtues, then science. ${ }^{39}$

[...] we have sought to make our presentation brief, and in our sweet and graceful vulgar language, so that those who understand a bit of Latin, or even thought they know it, they are unable due to the lack of time to reread such a plethora of obscure and confused argumentations, may at least have this little work of ours, and in enjoyment reading it, may thereby easily satisfy their desires. ${ }^{40}$

[...] this subject-matter is the most elevated and deepest that may be treated within the confines of natural sciences. And so far it may be said not to have been understood by those who have set themselves to examining it, so diverse and obscure have their utterances been, but it has been made so clear that its secrets could not be more fully revealed [...] moved to pity thinking of the benefit that the scholars of humanities could draw therefrom, I have gathered it together and undertaken to publish it. ${ }^{41}$

39. Benedetto Varchi, Opere, Vol. 2 (Trieste: Llyod, 1859), 490: "ciascuno prudente uomo e giudizio debbe ingegnarsi con tutto il poter suo che gli idioti e volgari uomini siano meno che si possa, e ciò altramente non può farsi che con l'insegnare loro prima le virtù, poscia le scienze."

40. Angelico Buonriccio, Paraphrasi sopra i tre libri dellanima d'Aristotile (Venice: Arrivabene, 1558), letter to the reader: "[...] questa nostra spositione l'habbiamo voluta fare brieve, \& nella nostra dolce \& leggiadra lingua vulgare, acciocché quelli, i quali sono poco intendenti delle latine lettere, overo se bene sono, non possono per la brevità del tempo rileggere una tanta moltitudine d’oscure \& confuse spositioni, habbiano almeno questa nostra operetta, la quale con diletto trascorrendo, possano agevolmente sodisfare a' loro desiderij."

41. Benedetto Dottori, Trattato de sogni secondo lopinione d'Aristotele (Padova: Pasquati, 1575), dedication written by Antonino Compagna: “[...] questa materia è la più alta, \& più profonda che trattarsi possa entro i termini della scientia naturale. Et si può dire che fin’horan non sia stata intesa, così diversamente, \& oscuramente n'han parlato coloro, che s'han proposto d'essaminarla, hora però è talmente fatta chiara, che cotai secreti non si poteano più manifestamente palesare [...] io mosso a pietà considerando quanto beneficio ne possano prendere i studiosi delle belle lettere, l'ho raccolta, \& mi son messo a pubblicarla." 


\section{e. Physics, astronomy, and meteorology}

It seemed to many ancient philosophers that to publish the sciences and make them clear to everyone was to throw away roses and pearls, and so they concealed what they knew with hieroglyphs, mysteries, fables, symbols, and enigmas, almost more than nature herself. And in so doing they showed themselves to be jealous of power and ungrateful, and unlike the giver of these and other graces. Even so there are some (albeit very few) who seek to defend them, saying that in this way the sciences maintained their reputation and dignity, because they were accessible only to fine minds and to the wealthy and important people. [...] And they say that by popularizing them and publishing them, good minds are put on a par with uncouth minds, and those who are notable and important with those who are low-caste and plebeian. Nor do they refrain from attacking those who have sought to defeat ignorance in the world and spread the sciences in all the languages. ${ }^{42}$

On the sphere of the world four books in the Tuscan language [...] reduced to such convenience and such an easy manner of demonstration that however little practice in the study of Mathematics will be sufficient to easily and quickly understand everything. ${ }^{43}$

Even here it has come to my attention (most noble and beautiful Madonna Laudomia) that having Your Ladyship found herself this past spring one

42. Piccolomini, Sopra le Mechaniche d'Aristotele, 4: "Parve à molti antichi filosofi, che il publicar le scienze, e farle chiare à tutti, fusse un gettar via le rose, e le perle, e perciò oscurono le cose conosciute da loro con hieroglifi, misterij, favole, simboli, \& enigmi, quasi più, che non fa l'istessa natura. Nel che si dimostronno invidiosi de poteri, \& ingrati, e dissimili al donator di quelle, e dogni gratia. Con tutto ciò si trovano alcuni (Se ben pochissimi) che cercan difenderli, con dire, che così facendo mantenevano le scienze nella reputazione e dignità loro, perché non eron capaci di quelle, se non i buoni ingegni, e le persone ricche, e principali. [...] E dicono che nel facilitarle, e pubblicarle, vengono pareggiati i buoni con i rozzi intelletti, e le persone illustri, e principali con le vili, e plebei. Ne si astengono dal biasimar coloro, che han tentato di scacciar l'ignoranza del mondo, e diffondere in tutte le lingue le scienze."

43. Alessandro Piccolomini, De la sfera del mondo (Venice: Del Pozzo, 1540), frontmatter: "De la sfera del mondo libri quattro in lingua toscana [...] ridotti a tanta agevolezza, \& a così facil modo di dimostrare che qual si voglia poco essercitato negli studij di Matematica potrà agevolissimamente \& con prestezza intenderne il tutto." 
day in the company of other most noble women in a garden [...] beautiful and scholarly and philosophical arguments occurred between you [...] I understood that Your Ladyship said that alongside the sorrow she has always felt, having been born a woman, not having had the opportunity to devote her years to some prestigious study and honourable science, and for this reason it pained her above all that she has not been able to nourish her soul with questions of Astrology, towards which she felt particularly drawn. [...] Having thus heard of such a pleasing desire, [...] I was inflamed with an equal desire to participate in such a great wish, as far as my strength would permit, by setting myself to bring together from the most famous and recognized authors who have written on matters astrological, everything that I considered most worthy of being known: because I have no doubt that however subtle and erudite the speculation, if it is not perfectly understood by Your Ladyship it is only because Your Ladyship has not been able to know certain things, which I believe to be because the Latin language was hidden from her, as a result of the malpractice of our times: which, since the sciences are not in our language, still prevents women from learning the language in which they are written: in this way it stops many women from entering into the study of the most excellent and rare letters [...] this little work on the Sphere of the World [...] having employed all my ability and diligence to reduce such things to such ease and clarity, that I am certain that anyone (man or woman), however little practice in the study of mathematics they have had, will be able to understand it very well [... ${ }^{44}$

44. Alessandro Piccolomini, De la sfera del mondo (Venice: Del Pozzo, 1540), dedication: "Mi è per insin qua venuto alorecchie (Nobilissima e Bellissima Madonna Laudomia) che trovandosi in questa Primavera passata, la S.V. un giorno con altre nobilissime Donne in un giardino, [...] bellissimi \& molti dotti e filosofici ragionamenti accader tra voi [...] intesi che la S.V. disse che oltra'l dispiacer chella ha sempre havuto, che per esser nata Donna, non le sia stato conceduto di poter donare gli anni suoi, a qualche pregiato studio \& honorata Scientia, per questo ciò le dolea più che per altro, chella non havea possuto pascer l'animo suo, de le cose d'Astrologia a le quali la si sentia più che ad altro inclinata. [...] Dunque un così bel suo desiderio, doppo che venutomal'orechie [...] maccese parimente d'ardente desio di voler in parte a così honorata voglia, per quanto si stendon le forze mie sodisfare, con l'ingegnarmi di raccoglier in lingua nostra dai più famosi et approvati Scrittori, che han trattato dele cose d'Astrologia, tutto quel che io giudicasse più degno d'esser saputo: perciò ch'io non dubito che quanto si voglia sottile \& dotta speculatione, non sia per esser da V.S. compresa benissimo, essendo che sola cagion che V.S. non habbia possuto alcune cose sapere, stimo io che sia lesserle stato ascosa la lingua latina, colpa dela 
Most gracious readers, who desire to read the writings of others, more out of a desire to learn than to criticize and malign; you have always been the only audience for my works [...] I want to warn you of certain things. Firstly, you must know that in all the works I have written until now, my primary intention has been to write as clearly as possible: seeking in every study to present the subjects to other intellects in a manner so plain, so accessible and free of difficulty, that not only fine intellects but also average ones can learn them. [...] I have always judged either envious or uncultured those who, the more the subjects they have set themselves to dealing with are wrapped in obscurity, the more instead of shedding light upon them, they seek, either with excessive brevity, or with words that are not well known, or with arrogant affected elegance, or, finally, by representing, while translating from one language to the other, things they do not understand, adding difficulties and hoping in this way to appear more scholarly. [...] for this reason I have tried to make the subjects accessible with known vocabulary and familiar expressions, stating, replying and exemplifying to shed light upon them: so that for this reason many times I have chosen to adopt a lower style, and a turn of phrase that is perhaps too domestic; because it did not seem to me useful for the Readers to do the opposite and leave things obscure. [...] even though these things that I deal with are written in our language, no one can claim that for this reason they can be read and understood with flowing ease, as if they were histories, or romances, because the difficulties of the sciences do not depend on the language, but are tied up with the subject itself, so that it is more the way in which they are written and expressed than the variety of language that will make them clear, hence I am writing them in our Tuscan language, because such a language will make them easier, but

\footnotetext{
mal'usanza dei nostri tempi: la qual da poi che le scientie non son nela lingua nostra, ne vieta ancora che le Donne non apprendin quella lingua, in chui le si truovano: così ne impedisce che molte Donne non venghin negli studi dele lettere escellentissime e rare [...] questa operetta dela Sfera del Mondo [...] havendo usato ogni ingegno, e diligentia di ridur tai cose a tanta facilità e chiarezza, che io tengo per certo che qual si voglia poco esercitato negli Studij di Matematica (o Donna o huomo che sia) potrà intenderle agevolissimamente [...]"
} 
only to release us, who are born in Italy, from the need to learn foreign languages before acquiring and discovering the sciences. ${ }^{45}$

My intention, most noble and judicious Reader, is to treat all those natural effects which the Greek Philosophers were wont to call Meteorological [...] My reason for writing such things is that every type of person desires to know about them: those for whom it is more a matter of honour and enjoyment to know the causes of honourable things [...] others for whom it is more useful [...] greatly wish to learn this doctrine, such as the fathers of families, so that they may foresee the abundance and lack of fodder, wines, oils, and other similar things that are required for the home. [...] The learned doctors make use of such noble and worthwhile knowledge not only for science but also in practical applications [...] so that they may predict what types of disease might occur [...] Those that travel by sea, whether to provision cities or to conduct naval warfare, these still make great use of such science, as it allows them to foresee

45. Alessandro Piccolomini, La prima parte dele theoriche overo speculationi dei pianeti (Venice: Varisco, 1558), letter to the readers: "Benignissimi Lettori, \& desiderosi di leggere gli altrui scritti, più per desiderio di sapere, che per voglia di riprendere, \& malignare; a voi soli ho io scritto sempre le opere mie [...] voglio voi d'alcune cose avvertire. Primieramente voi havete da sapere che in tutte quelle opere che io ho scritte fin qui, ho havuto più che ad altro intentione a scrivere con quella maggior chiarezza, che è stato a me possibile: procurando con ogni studio di mettere innanzi agli altrui intelletti le materie così piane, così agevolate, \& sciolte di difficultà, che non solo li sottili intelletti, ma li mediocri ancora le possino apprendere. [...] ho io sempre giudicato, o invidiosi, o poco dotti coloro, li quali, quanto più li soggetti di cui han preso a trattare sono involti di oscurità, tanto più in cambio di dar lor luce, si ingegnano, o con troppa brevità, o con vocaboli poco noti, o con soverchia affettata elegantia, o finalmente con depingere, da una lingua transportando nel'altra, le cose che non intendano, aggiugnere difficultà, sperando forse per questo parer più dotti. [...] per queta cagione ho cercato di aprire le materie, \& con vocaboli manifesti, \& modi di dire familiari, dichiarando, replicando, \& esemplificando dar lor luce: in tanto che per questo molte volte ho più presto voluto descendere a uno stile piutosto basso che no, \& a un modo di dire troppo forse domestico; che con fare il contrario lascar le cose più oscure, che al'util dei Lettori non mi è paruto di convenire. [...] seben queste cose, che io tratto sono scritte in nostra lingua; non per questo ha da stimarsi alcuno che si possin leggendo intender con quella agevolezza scorrendo, che se fossero historie, o novelle, percioche le difficultà dele scientie non dependano dala lingua, ma son congiunte con le cose stesse, di maniera che più il modo di dirle, \& di esprimerle, che le varietà dele lingue le posson far chiare, ne le scrivo io in questa lingua nostra Toscana, perché tal lingua le faccia più facili, ma solo per torre a noi che nasciamo in Italia la necessità di apprender le lingue esterne per poter acquistare \& trovar le scientie [...]." 
whether they will be facing contrary or favourable winds [...] I shall give a brief treatment [of the natural effects] so that no one may be affronted by the length. [...] And it pleases me to discourse on these things no less in this Tuscan, or rather Florentine, language of ours than in Latin, to both benefit and please each person. ${ }^{46}$

This is but a brief sample; however, these voices echoing from the past provide us with important clues as to what a likely public for Aristotle's works could be. At least two levels of public may be discerned.

At a more general level, the recipient group includes the largest possible number of people, including "idiots," "simple minds," "ignorants," and "illiterates"; in other words, people who potentially lacked the culture to access higher knowledge. ${ }^{47}$ As so valuably suggested by Elizabeth Eisenstein, the majority of

46. Francesco Verino, Trattato delle Methore (Florence: Marescotti, 1578), letter to the reader: "L'intentione mia è nobilissimo, \& giudiziosissimo Lettore di trattare di tutti quelli effetti naturali, i quali da' Filosofi greci comunemente son chiamati Metheorologici [...] La cagione che mi muove a scrivere di cosifatte cose è, perché ogni sorte di persone desidera haverne qualche notizia: quelli ne' quali può più l'honore, \& il diletto di cose honorate hanno gran voglia di saperne la causa [...] gli altri ne quali può più l'utile $[. .$.$] son molto disiderosi di apparare questa dottrina, come i padri di famiglia, perciocché$ con questa antiveggono l'abbondanza, \& carestia de' grandi, biade, vini, olii, \& di simili altre cose necessarie alla casa. [...] I Medici dotti non meno per scienza, che per molta pratica approvati ancor essi vagliono di così gentile \& utile cognizione [...] così preveggono che sorte di inferimità possono avvenire [...] Quelli che vanno per mare, o sia per provedere di Mercanzie le città, osia per conto di condurre gente per guerra Marittima ancor questi fanno un gran conto di così fatta scienza, potendo per essa prevedere se hanno a tirare venti contrarii, o pure prosperi [...] Io con brevità ne discorrerò [degli effetti naturali] acciocché nessuno dalla lunghezza [sia] infastidito. [...] Emmi piaciuto parlare di queste cose, non meno in questa nostra lingua Toscana, o per dir meglio Fiorentina, che io mi faccia ancora nella latina, per giovare, \& dilettare insieme ognuno [...]”

47. In this paper I will adopt expressions such as "idiots," "simple minds," and "vulgars," which at that time did not necessarily imply a derogatory attitude, as they do in current English. See Gigliola Fragnito, Proibito capire. La Chiesa e il volgare nella prima età moderna (Bologna: il Mulino, 2005), 272. Similarly, "illiterates" were for the most part those who were not capable of reading, writing, and speaking Latin, hence in modern terms they may well have been literate. See Herbert Grundmann, "Litteratusilliteratus: Der Wandel einer Bildungsnorm vom Altertum zum Mittelalter," Archiv fur Kulturgeschichte 40 (1958), 1-65. Translations of idioti, volgari, semplici, ignoranti, etc., have been kept literal because it would be impossible to render the wide spectrum of terms with a couple of neutral words. On the use of these expressions in the Italian language, see Marina Roggero, Insegnar lettere. Richerche di storia dell'istruzione in età moderna (Alessandria: Edizioni dell'Orso, 1992); Marina Roggero, Le carte piene di sogni. Testi e lettori in età moderna (Bologna: Il Mulino 2006). 
the population at that time did not know how to read, and there remained a clear distinction between literacy and familiarity with reading, between learning to read and learning through reading. In other words, knowing how to read did not necessarily mean that a person would actually read or acquire new knowledge. ${ }^{48}$ The "illiterates" and those who had rudimentary knowledge were thus divided by clearly distinguished degrees of culture that corresponded to different levels of access to knowledge. ${ }^{49}$ Gigliola Fragnito correctly writes that "there was the literacy of those who knew how to read and write, the semi-literacy of those who had varying degrees of ability to read, and absolute illiteracy." ${ }^{\prime 0}$ The social and economic conditions that determined the level of a person's education differed enormously, even among the illiterates. ${ }^{51}$ As we shall see, while some acquired the rudiments of an education in the home or the workshop, others were self-taught and built an education primarily on their contact with the book; some were able to attend parish schools, while others went to abacus schools. Having the means to attend a university or hire a topnotch private tutor was therefore not the only factor discriminating between literates and illiterates. ${ }^{52}$ Moreover, literacy was by no means the only barrier

48. Elizabeth L. Eisenstein, The Printing Press as an Agent of Change: Communications and Cultural Transformations in Early-Modern Europe (Cambridge: Cambridge University Press, 1979), 65-66. On Eisenstein, see Anthony Grafton, “The Importance of Being Printed," The Journal of Inderdisciplinary History 2 (1980): 265-86.

49. Paolo Trovato and Pietro Trifone have shown that literacy rate statistics for Renaissance Italy are unreliable because reading and linguistic skills generally varied not only among the different social classes but also within the same social class. See Trovato, 17-33; Pietro Trifone, Rinascimento dal Basso. Il nuovo spazio del volgare tra Quattro e Cinquecento (Rome: Bulzoni, 2006), 143-63.

50. Fragnito, Proibito capire, 269.

51. Roger Chartier suggests that "the printed word was familiar even to those who could not read, in workshops, in the Protestant churches, and in the festive confraternities. Addressed in common, taught by some and deciphered by others, deeply integrated into the life of the community, the printed word laid its mark on the urban culture of the popular masses. And it thus created a public, and therefore a market, beyond those who were literate and even those who read books. In fact, between 1530 and 1660, for the majority of the popular urban classes, the relation to the printed material is not a relation to books [...]." Roger Chartier, "Culture as Appropriation: Popular Cultural Uses in Early Modern France," in Understanding Popular Culture: Europe from the Middle Ages to the Nineteenth Century, ed. Steven L. Kaplan (Berlin: Mouton, 1984), 243.

52. On education in Renaissance Italy with particular reference to vernacular teachings, see Grendler, Schooling in Renaissance Italy, 275-332; Robert Black, Humanism and Education in Medieval and Renaissance Italy (Cambridge: Cambridge University Press, 2001), 275-81, 301-05. 
standing between the common people and the educated classes. The availability of vernacular works, whether printed or manuscript, not to mention their cost, and the existence of social occasions in which such works could be read aloud, were all factors that had a profound influence on the consumption of cultural products.

Why Aristotle's works should be directed at social groups with such a low level of education is a moot question. An initial, if partial, answer may be found in the passages cited above. These works are most commonly described as "benefitting" such people and increasing their knowledge..$^{53}$ There is also a second level where works have specific recipients and therefore also purposes that go beyond benefitting the person in a general sense. Antonio Scaino and Felice Figliucci, for instance, dedicate their works to men involved in politics who govern the city. Panfilo Persico is even more explicit in addressing his writings to princes and those who govern the republic and the court. Far from being uneducated, these social groups frequently had knowledge of classical languages, or at least some degree of erudition, but still it was easier for them to read in the vernacular rather than a language that was no longer spoken. ${ }^{54}$ The works of Benedetto Dottori and Ludovico Castelvetro were aimed at a similar, if not higher, cultural milieu: men of letters, poets, and literary critics. That both Dottori and Castelvetro addressed their writings to men of letters with a certain level of erudition who were therefore steeped in classical literature serves to explain the complexity of their works. Yet the fact that they were written in the vernacular instead of Latin, as would have been the case only thirty or forty years before, shows how profound a shift the studia humanitatis were going through, and how the new humanism conceived in the academies

53. The benefit and accretion of knowledge they bestow are to serve all human beings in fulfilling their essence as rational beings who by their very nature wish to know, as Aristotle himself asserts at the beginning of the Metaphysica. And from this knowledge, again in Aristotelian terms, derives happiness, since happiness results from the fulfilment of one's nature. Benefitting others, as we shall see in more detail below, is a duty that human beings must perform by virtue of the fact that a human being's nature consists in the perfection of knowledge, which will also lead to the perfection of practical activities and therefore greater happiness. See Maria Pia Ellero, "I volgarizzamenti e la felicità mentale: l'umana perfezione nella Filosofia naturale di Alessandro Piccolomini," in Lo scaffale della biblioteca scientifica in volgare (secoli XIII-XVI), ed. Rita Librandi and Rosa Piro (Florence: Sismel-Edizioni del Galluzzo, 2006), 453-68.

54. A striking example is the Doge Leonardo Donà, who knew Latin, but read the Bible in the vernacular. See Fragnito, Proibito capire, 265. 
mostly spoke the vernacular rather than Latin. The Loica by Venetian physician Niccolò Massa, for instance, being addressed "not only to Philosophers and Rhetoricians, but also Grammarians, Historians, and other men of letters," namely to all those who in the fifteenth century pursued the studia humanitatis, that is to say the humanists, is a case in point. ${ }^{55}$ Writing in the vernacular was no mere literary exercise for these new intellectuals: they were effectively expanding the recipient base for Aristotelian texts.

For many vernacular writers, however, the educated upper classes were not the only intended recipients. Giovan Battista Gelli was animated by a need to teach philosophy also to woodcutters and apothecaries, ${ }^{56}$ while Claudio Tolomei viewed the knowledge of mechanics as an important acquisition for sculptors, painters, carpenters, and architects too. ${ }^{57}$ Mechanics, as Niccolò Tartaglia wrote in the frontispiece of his Scientia nova, was an important subject also for "bombardiers" - that is, artillerymen and men of war-and not only for so-called "speculative mathematicians," 58 whereas Francesco Verino declared that the natural phenomena investigated in the Meteorologica would be of interest to any who read it, whether for "honour" or "pleasure," simply because such phenomena give rise to "marvellous things," or for practical purposes, ${ }^{59}$ such as the paterfamilias, who must keep the home stocked with food, the doctor, who can discover the causes of diseases and their remedies, and navigators, both mercantile and military, who can anticipate adverse weather conditions. Works targeting specific recipient groups were usually concerned with ethical-political

55. Niccolò Massa, Loica (Venice: Bindoni, 1549), frontmatter.

56. On the apothecary as a hub of information and communication, see Filippo De Vivo, "Pharmacies as Centres of Communication in Early Modern Venice," Renaissance Studies 21 (2007): 505-21.

57. Tolomei Claudio, Delle lettere libri sette (Venice: Giolito, 1547), 82r-v: "Matters relating to architecture are very popular and widely practiced nowadays among men who have little knowledge of the Latin language, and likewise among sculptors, painters, master carpenters, and vulgar architects. [...] It will therefore be of benefit to the world to provide a new translation of Vitruvius in the beautiful Tuscan language [...]" ("Le cose d’architettura sono disiderate assai e praticate oggidì da huomini che non hanno molta intelligenza di lingua latina, sì come scoltori, dipintori, maestri di legname, e architettori volgari. [...] Farassi dunque ancor questo utile al mondo, traducendo nuovamente Vitruvio in bella lingua toscana [...]").

58. Niccolò Tartaglia, Inventione novamente trovata [...] utilissima per ciascuno speculativo Mathematico, Bombardiero et altri intitolata Scientia nova (Sabbio: Venice, 1537), ${ }^{*}$ ii.

59. Craig Martin, "Meteorology for Courtiers and Ladies: Vernacular Aristotelianism in Renaissance Italy, Philosophical Readings 2 (2012): 3-14. 
matters (ethics, politics, rhetoric), or applied sciences (mechanics and meteorology), ${ }^{60}$ and sometimes differed from Latin works in that they contained a practical knowledge that their public would apply. ${ }^{61}$ Furthermore, that such targeted groups did not consist only of men is demonstrated by Alessandro Piccolomini, some of whose works were written for women. In their roles as nannies and wet-nurses, women with access to culture were perfectly placed to become themselves vehicles in the education of children, who were in this manner exposed from their earliest years to works which were probably read to them in infancy, and which they would later go on to memorize. ${ }^{62}$ Hence we might say that a substantial cross-section of the population was the intended recipient of these works, and therefore that the cultural consumer base was thus greatly expanded. ${ }^{63}$

These were the "people" targeted by Aristotle's vulgarizers. ${ }^{64}$ They included "groups at the bottom, or on the margins, such as unskilled workers, hired labourers, peasants, or the poor," and not only, as Andrea Zorzi has pointed

60. It is important to note that "usually" does not mean "exclusively." As we shall see, vernacular Aristotelianism was a theoretically engaged philosophical movement.

61. See for example the genre of advice written for politicians and governors in Valentina Lepri, Layered Wisdom: Early Modern Collections of Political Precepts (CLEUP: Padova, 2015).

62. Fragnito, Proibito capire, 275-87.

63. There were handbooks for teaching adults, such as artisans and women, to read without going to school. For sixteenth-century Rome, see Armando Petrucci, "Scrittura, alfabetismo ed educazione grafica nella Roma del primo Cinquecento: da un libretto di conti di Maddalena Pizzicarola in Trastevere," Scrittura e civiltà 2 (1978): 163-207. For sixteenth-century Venice, see Piero Lucchi, "La Santacroce, il Salterio e il Babuino: Libri per imparare a leggere nel primo secolo della stampa," Quaderni storici 38 (1978): 593-630; Piero Lucchi, "Leggere scrivere e abbaco: L’istruzione elementare agli inizi delletà moderna," in Scienze, credenze occulte, livelli di cultura (Florence: Olschki, 1982), 101-19; Paul F. Grendler, "What Zuanne Read in School: Vernacular Texts in Sixteenth Century Venetian Schools," The Sixteenth Century Journal 13 (1982): 41-54; Anne Jacobson Schutte, "Teaching Adults to Read in Sixteenth-Century Venice: Giovanni Antonio Tagliente's Libro Maistrevole," Sixteenth Century Journal 17 (1986): 3-16.

64. The historical and literary basis for the meaning of "people" adopted in this paper can be found in what may be considered the most important programmatic work of vernacular humanism in the Cinquecento: Pietro Bembo's Prose della volgar lingua, where "people" is synonymous with "masses" (volgo), "commoners" (popolani), "populace" (genti), "multitude" (moltitudine), "uneducated" (non dotti), and also "peasants" (contadini). Unlike Aristotle's vulgarizers, however, Pietro Bembo uses the term "people" in a derogatory sense and advances an aristocratic idea of culture in which "very few men in each century" have knowledge. Nonetheless, "people" was a general term used to designate low social 
out in the context of political history, the "self-employed artisans organized in occupational guilds, skilled workers, masters and foremen, small traders and entrepreneurs, small property owners, notaries, teachers, and doctors," all of whom established themselves in opposition to the "nobles" and the "knightly aristocracy."65

In his Battaglie (1582), Girolamo Muzio wrote that the intention of every author is to "offer usefulness" and benefit "to lords and gentlemen; soldiers and sappers; merchants; men; women; the young; the old; the learned; the uneducated; in other words to everyone regardless of age and sex, whatever their condition." ${ }^{66}$ The range of recipients presented by Muzio is as wide as the variety of themes that are to be treated, from Aristotelian philosophy to the most practical disciplines:

If you wish to treat of divine matters [...] is it not more expedient to do so in Italian, so that those who know nothing of those beautiful things and lofty mysteries may learn them from you [...]? I shall say the same about Philosophy, which contemplates nature; and even more so of ethics. [...] But to speak of more particular things: wanting to write of the art of war, is it not right that the captains and soldiers should understand you? And of architecture, is it not best that the engineers and masters of workshops should be able to learn from our teachings? And of agriculture, does it not seem necessary for you that the men of the people should profit from them? And of arithmetic, should it not be your intention that even the

\footnotetext{
classes or indistinct masses. See Pietro Bembo, Prose della volgar lingua, ed. Carlo Dionisotti (Torino: UTET, 1931), 31-32.

65. Andrea Zorzi, "The popolo," in Italy in the Age of The Renaissance 1300-1550, ed. John M. Najemy (Oxford: Oxford University Press, 2004), 145.

66. Girolamo Muzio, Battaglie (Venice: Dusinelli, 1582), 160v: "Se voi volete trattar le cose divine [...] non è più convenevole scriver Italicamente, a fine, che color, che non sanno quelle cose belle, \& quegli alti misteri, gli apparino da voi [...]? questo medesimo dirò io della Filosofia contemplatrice della natura; \& della morale maggiormente. [...] Ma per venire alle cose piu particolari: Volendo scrivere della arte della guerra, non è egli buono, che i Capitani, \& i soldati vi intendano? Se di Architettura, non è egli convenevole, che gli ingegneri, \& maestri delle fabbriche possano apprender i nostri ammaestramenti? Se di Agricolotura, non vi par necessario, che gli huomini del popolo ne possano trar utilità? Se di Arithmetica, non dee esser vostra intention, che anche gli huomini non letterati vi debbano poter leggere? [...] Questo a me sembra, che officio sia di huomo letterato \& di buon scrittore."
} 
uneducated understand you? [...] It seems to me that this is the task of the man of letters and the good writer. ${ }^{67}$

We can therefore speak in very concrete terms of a relationship between Aristotle and the people. ${ }^{68}$

It is natural to want to know at this point whether this public, these consumers of Aristotelian vulgarizations, did in fact exist, or whether they were a completely invented fabrication, perhaps for commercial purposes just to sell more books to a greater number of people. ${ }^{69}$ Put differently, we might want to ask whether there was at least a partial correspondence between public and audience. Again, a preliminary study of the public is necessary to gain some insight into the nature of the audience, because someone who writes is writing for someone, for instance artisans, women, or merchants. In absolute terms, we might say, to quote Giovan Battista Gelli, that "anyone who writes does so for no other reason than that his things, preserved as letters, which do not disappear like voices, may be understood by the whole world."70 If the social groups to which such works were explicitly addressed had not existed as a prototype readership, or it had not been possible to create them as a new type of literary space, the writer would either not have written at all or he would have stopped writing altogether. ${ }^{71}$

67. Muzio, Battaglie, 187r-187v. On this passage, see Vittorio Coletti, Parole dal Pulpito. Chiesa e movimenti religiosi tra latino e volgare (Casale Monferrato: Marietti, 1983), 163.

68. Another possible definition of people is proposed by Roger Chartier following Daniel Roche: "I take 'popular classes' to mean, by default, readers who did not belong to 'the three robes' [...]: the black robe of the clerics; the short robe of the nobility; and the long robe of a varied group of low- or high-grade officials, lawyers, and attorneys, to which must be added the medical profession. Thus I identify the following as belonging to the 'popular' class: peasants, master craftsmen and their journeymen, and merchants, including those who have retired from business and style themselves 'bourgeois."' Chartier, "Culture as Appropriation," 237-38.

69. Paolo Veneziani, "Il frontespizio come etichetta del prodotto," in Il libro italiano del Cinquecento. Produzione e commercio (Rome: Istituto poligrafico e Zecca dello Stato, 1989), 99-125.

70. Gelli, 202.

71. It is in fact highly improbable that over three hundred works should have had an entirely fictional, hence not real, public whose sole purpose was to justify the use of the vernacular. Not only would such a conceit reduce vernacular works to a mere literary exercise, it would also effectively constitute a deliberate red herring on a collective scale, as if all vulgarizers, or at least most of them, had made a pact to address their works to a public that did not exist. Furthermore, the motivation and intentions 
That such social groups did in fact exist is borne out by at least one factor that may be evinced from the parallel phenomenon of biblical vulgarizations promoted by reformist groups in Italy, but not, as one might expect, through those who supported an across-the-board program of religious re-education for the populace. Conservative intellectuals on all sides, who opposed the vulgarization of knowledge, were reacting against an endeavour that was clearly proving successful, otherwise they would not have opposed vulgarizations so violently. This movement against vulgarizations and vulgarizers banishes all doubt regarding the possibility that the programmatic statements of vulgarizers were purely propagandistic, and therefore directed at a fictional, non-existent public. The Franciscan friar, Giovanni da Fano, wrote against the "Lutheran heresy" for the edification of those who were "illiterate and simple"; in other words, for "idiot men, women and children."72 The very idea of extending knowledge to "cobblers, bronzesmiths, scrap metal merchants, butchers, dyers, wool cleaners, wool beaters, builders and blacksmiths,"73 not to mention "the

behind such a masquerade en masse would require explaining, and there is simply nothing in the explicit statements of these intellectuals to suggest anything that might support such a view. One would have to build arguments on what was not said rather than what was said purely on the assumption that there can be no correspondence between audience and public in the various types of vulgarization. One would have to choose the "unspoken" facts of the historians over the direct statements of the sources. Even if this were possible, one would then have to explain how to talk about this "unspoken" material. As we have seen, vulgarization techniques and linguistic register are not always reliable indicators, because if these vulgarizations aim to educate, and not be mere literary exercises, the primary purpose is the improvement of knowledge, which means imparting information and language that a person did not have before, and are therefore difficult to understand. Any process of "instruction," however "simplified," requires raising the level of culture and providing a terminology and a knowledge that previously did not exist.

72. Giovanni Pili da Fano, Opera utilissima vulgare contra le pernitiosissime heresie lutherane per li simplici (Bologna: Phello, 1532), 1v. On Pili, see Silvano Cavazza, Luthero fedelissimo inimico de messer Jesu Christo. La polemica contro Lutero nella letteratura religiosa in volgare della prima metà del Cinquecento, in Lutero in Italia. Studi storici nel V centenario della nascita (Casale Monferrato: Marietti, 1983), 67-94; Gian Luigi Betti, "Alcune considerazioni riguardo all'Incendio de zizanie lutherane di Giovanni da Fano pubblicato a Bologna nel 1532," Archiginnasio. Bollettino della Biblioteca Comunale di Bologna 82 (1987): 235-43; Sebastiano da Potenza, "L'incendio di zizanie lutherane di p. Giovanni da Fano," Italia francescana 36 (1961): 188-96, 426-31.

73. Lorenzo Davidico, Anotomia delli vitii (Florence, 1550), 327. See Massimo Firpo, Nel labirinto del mondo. Lorenzo Davidico tra santi, eretici, inquisitori (Florence: Olschki, 1992), 96-97; Massimo Firpo, Riforma protestante ed eresie nell'Italia del Cinquecento (Bari-Rome: Laterza, 1993), 10. 
tailors, the woodcutters, and other low-born scum"74 was hard to accept. Yet, as Dominican friar Ambrogio Catarino Politi, the great castigator of Antonio Brucioli, translator of the Bible and of Aristotle,${ }^{75}$ was forced to admit, "human curiosity and presumption, [...] has reached the point today that any person, whatever their circumstances, whether woman or man, whether idiot, uneducated, or educated, wants to understand profound matters of sacred theology and Holy Scripture." ${ }^{76}$ As this handful of testimonies indicates, the social classes mentioned by those who opposed the vulgarization of biblical lore were the very same recipient groups targeted by Aristotle's vulgarizers, which suggests that such an audience not only existed but was capable of reading complex doctrines, a fact of no small concern to the religious authorities. And if they were capable of grasping the truth of the Bible, theology, and Revelation, one might argue that they were also capable of understanding the rational truths offered by philosophy, albeit partially and with some degree of effort. No doubt, the level of penetration of the Holy Scriptures was higher than that of the philosophical texts, because there were more social chances to have contact with biblical messages; nonetheless, the public was the same.

\section{What does it mean to vulgarize?}

That philosophical works could indeed be directed at groups at the bottom or on the margins such as illiterates, idiots, simple people, and labourers may indeed cause suspicion or raise doubts. Can Aristotle really have had such widespread influence and such large publics at a time when literacy rates were so low? How deeply did the knowledge of Aristotle penetrate society, reaching even the populace? Such questions would require a series of micro-historical and sociological studies of culture aimed at reconstructing the knowledge of the so-called lower

74. Vincenzo Ferrini, Della lima universale de' vitii (Venice: Giunti, 1607), 308r. All these accounts are examined in Firpo, "Riforma religiosa e lingua volgare nell'Italia del Cinquecento," Belfagor 57 (2007): 537-38.

75. Giorgio Spini, Tra Rinascimento e Riforma. Antonio Brucioli (Florence: La Nuova Italia, 1940), 107. 76. Ambrogio Catarino Politi, Compendio derrori et inganni luterani contenuti in un libretto senza nome de lautore, intitolato "Trattato utilissimo del benefitio di Christo crucifisso," Roma, Ne la contrada del Pellegrino, ed. Massimo Firpo, in Benedetto da Mantova, Il beneficio di Cristo, ed. Salvatore Caponetto (Florence and Chicago: Sansoni / The Newberry Library, 1972), 347. On Politi, see Coletti, 139-40; Giorgio Caravale, Sulle tracce delleresia. Ambrogio Catarino Politi (1484-1553) (Florence: Olschki, 2007). 
classes, studies that would be severely hampered by the volatile, oral nature of popular culture. At most, one could seek to reconstruct the book heritage, but this too would yield only a partial picture of the culture of the period. As Zemon Davis has rightly pointed out, common people did not need to collect books privately in order to have access to them: (1) they could purchase a book or a manuscript, ${ }^{77}$ and then sell it on once having read it; (2) reading groups could disseminate knowledge orally (for instance in rural areas ${ }^{78}$ or printing houses); (3) certain works, like those on mathematical calculus, were available in shops, and therefore accessible to apprentices as well as shopkeepers; ${ }^{79}(4)$ other works were intended to be distributed orally, such as sermons, songs, and speeches. It would therefore seem wiser, at this early stage in our inquiry, to focus on the general motivations that drove these vulgarizers and explain what "vulgarizing" meant to them.

To think that the transfer of Greco-Roman culture to vernacular culture necessarily entailed a simplification would be misguided ${ }^{80}$ The widespread distribution of a vast number of theoretically demanding Aristotelian texts-for instance, on the question of the immortality of the soul, which until the 1540 s was debated almost exclusively in the universities but thereafter became common currency in vernacular writings too ${ }^{81}$-flies in the face of the view that the vernacular was restricted to works of a purely informational nature, such as

77. A key factor in the circulation of vernacular Aristotelian works was the widely used practice of personally transcribing manuscripts: printing "did not immediately displace the ms. trade [...] The average library, whether public or private, contained mss. as well as printed books [...] a doctor might have one treatise of Aristotle in printed form and another in ms. form"; George Sarton, Appreciation of Ancient and Medieval Science During the Renaissance 1450-1600 (New York: Barnes, 1958), 4.

78. Of particular interest, and characteristic of the times, are reading groups of women and Protestants. For the latter especially it was extremely dangerous to hold works that were considered heretical, and which were therefore frequently disseminated orally. See Fragnito, Proibito capire, 261-310.

79. On these points, Natalie Zemon Davis is emphatic; see her Society and Culture in Early Modern France, 212-13.

80. Loris Sturlese, "Filosofia in volgare," in Filosofia in volgare nel Medioevo, ed. Loris Sturlese and Nadia Bray (Louvain-la-Neuve: Fédération Internationale des Instituts d’Etudes Médiévales, 2003), 9; Bianchi, "Volgarizzare Aristotele", 493.

81. An example was recently provided in Marco Sgarbi, "Benedetto Varchi on the Soul: Vernacular Aristotelianism between Reason and Faith," Journal of the History of Ideas 76 (2015): 1-23; Marco Sgarbi, Profumo d'immortalità. Controversie sullanima nella filosofia volgare del Rinascimento (Rome: Carocci, 2016). 
'the 'secret books', or recipe books (pertaining to medicine, chemistry, cosmetics, cookery, etc.), a type of publication that enjoyed great success, but which because of its empirical nature was markedly different from academic and scientific treatises, which were generally written in Latin." ${ }^{82}$ Vernacular treatments thus covered a wide range of topics, including many that were studied in the universities, the difference being that they were approached in different ways and from different perspectives.

The many different approaches to vulgarization gave rise to such a varied array of vernacular texts that it is difficult to generalize its process. Nonetheless, the use of the vernacular as opposed to Latin is justified in all these works by the underlying notion that to vulgarize meant above all else to make what had hitherto been the preserve of a restricted clique of intellectuals available to a much wider public. For Alessandro Piccolomini, perhaps the greatest vulgarizer of Aristotelian works in the Cinquecento, the purpose of vulgarizing was "bringing those [Aristotelian] doctrines [...] into our language, which is well suited [...] to every science," as well as "to untie, and open up, and illuminate a subject so as to make it accessible, and so open in its intelligence that any who are not entirely uncouth and without ability may understand it, at least most of it." ${ }^{33}$ The techniques that were employed to make knowledge more accessible to any "uncouth and incapable" intellect, some of which we have already encountered in the examples cited above, differ from those used in straightforward translation. In the words of Piccolomini, a text may be vulgarized by "translating, commenting, or even expounding, annotating, paraphrasing, and abridging $[\ldots]$ be it with pure comments, annotations, epitomes, or summaries." ${ }^{84}$ Intellectuals frequently rejected literal translations, for which Piccolomini gives a number of reasons. First, translation requires "perfect knowledge of the language of the writer," whereas a vulgarizer may rephrase, extend, or add clauses and sentences while remaining as close as possible to the author's intended meaning. Second, a translator is more exposed to criticism,

82. Claudio Marazzini, Storia della lingua italiana. Il secondo Cinquecento e il Seicento (Bologna: il Mulino, 1993), 30.

83. Alessandro Piccolomini, Copiosissima parafrase di M. Alessandro Piccolomini nel primo libro della Retorica di Aristotele (Venice: Varisco, 1565), 4-5.

84. Alessandro Piccolomini, Annotationi di M. Alessandro Piccolomini, nel libro della Poetica d'Aristotele, con la traduttione del medesimo libro, in lingua volgare (Venice: Guarisco-Compagni, 1575), letter to the readers. Alessandro Piccolomini, La prima parte della filosofia naturale (Rome: Valgrisi, 1551), 1br-v. 
since, unlike in commentary or paraphrase, failure to adhere to a text is seen as a mistake. Third, one must have a firm grasp not only of the author's language, but also of the content of the text. It is particularly difficult in Piccolomini's view to find translators who are expert at correctly translating grammatical and syntactic structures as well as understanding the content of a text. Translators frequently focus on one or the other, either way failing to convey the author's intended meaning. Worse by far is to translate mere linguistic form at the expense of content:

some $[\ldots]$ without conveying, as they should, the meaning and the sentiment, proceed word-by-word, minimal particle by minimal particle, seeking to reproduce however many they find, taking care, as if they were counting them, not to short-change the end result, thus producing a garbled and insipid form of expression, and, what is worse, one that is for the most part unintelligible. ${ }^{85}$

This was, in Piccolomini's view, the main problem with vulgarization. If to vulgarize means to transmit knowledge, then properly conveying the content and message of the text took precedence over translating the words-a position that was not as unique in the panorama of Aristotelian vulgarizations as one might think.

Far from being a merely hypothetical statement, what Piccolomini is describing here is the general state of vulgarization in the Cinquecento. Statistically speaking, only 16 percent of all vernacular Aristotelian works were proper translations. Treatises were most common at 29 percent, followed by summaries and compendia at 24 percent, dialogues at 18 percent, and paraphrases at 3 percent. Less numerous than translations were commentaries at 5 percent, lectures and speeches at 4 percent, and letters at a mere 1 percent. ${ }^{86}$ Translation was therefore not the first choice of method for vulgarizing Aristotle's

85. Piccolomini, Annotationi, letters to the readers: "alcuni [...] senza a procurare, come far doverebbero, principalmente la sententia, \& il sentimento, vanno di parola in parola, \& di minima particella in particella cercando di recarne a punto tante, quante ve ne truovano, \& guardandosi, come se le havesser prese a conto, di non defraudar in restituirle nel numero, vengono a produrre una sorte di locutione confusa, insipida, \& quel chè peggio, per la maggior parte inintelligibile.”

86. Statistics are grounded in Vernacular Aristotelianism in Renaissance Italy Database (=VARI): http://warwick.ac.uk/vernaculararistotelianismdatabase. See Eugenio Refini, "Per un database 
philosophy. The method of vulgarization was an important factor in determining how many recipients were reached, as a closer examination of these works divided by genre will reveal. Summaries, compendia, and dialogues, which combined account for 42 percent, or almost half of the total number of vulgarizations, were the most accessible, meaning that they were easier and more likely to attract a large number of recipients, despite sometimes, albeit infrequently, over-simplifying the material. Translations, on the other hand, along with commentaries and paraphrases, while accounting for a good 24 percent of the total number of works, frequently adopted complex terminology, sometimes transposed directly from Greek and Latin, and tended to become embroiled in lengthy disquisitions on difficult and complex passages, which deserved fuller treatment.

In many of the cases examined above, to vulgarize philosophical content meant also to popularize it; in other words, to reach the common people with content that was traditionally not intended for them. For those who were not used to a particular type of language or certain kinds of ideas, rhetorical devices could be used to aid understanding and provide greater access to philosophical content. Such was the case with the Aristotelian Francesco Robortello, who viewed rhetoric as a useful aid to making philosophy easier to understand and more relevant for a wider public. Like Piccolomini, Robortello was well aware that the process of making philosophical content more comprehensible could result in the failure to accurately convey the ideas of the source text, but this was not equivalent to deceiving or conveying knowledge in an erroneous or simplified form. Rather it meant making the acquisition of in-depth and detailed knowledge possible for all kinds of people. In his De artificio dicendi (1567), Robortello demonstrates how rhetoric and oratory can be used to make philosophical truth accessible to common people. The task of rhetoric was to clarify knowledge, thus enabling common people to make informed judgments of their own about what they were learning. ${ }^{87}$ The real problem for Robortello was that philosophy used abstract words that few could understand, while the people wanted words that denoted concrete objects and could instantly be understood, and therefore also shared. This was the key to translating and

dell'aristotelismo volgare in Italia (c. 1400-c. 1650)," in "Aristotele fatto volgare": Tradizione aristotelica e cultura volgare nel Rinascimento, ed. D.A. Lines and E. Refini (Pisa: ETS, 2015), 201-06.

87. Francesco Robortello, De artificio dicendi (Bologna: Benati, 1567), 9r-v. 
vulgarizing philosophical discourse. Robortello identified four different ways to popularize philosophy; in other words, to make a difficult philosophical text accessible to a wider range of recipients. The first was to make an abstract notion more concrete by means of the rhetorical inference of example: one specific case was valid for all other similar cases. The second was to transform a universal concept into a particular concept. Thus, for instance, in moral philosophy one should deal with happiness not according to its definition but in reference to the happy man. ${ }^{88}$ The third was to use metaphor to convey philosophical concepts. The fourth was to employ as many words and phrases as were necessary to explain and clarify a philosophical concept. ${ }^{89}$ Rhetoric for Robortello was thus a way of reaching a wider public, but it did not necessarily mean trivializing philosophy. On the contrary, Robortello's guiding principle was first to explain specific terms in the various arts and sciences, also with reference to their meanings in Greek and Latin, and only then to give a translation in the common vernacular language. ${ }^{90}$ This, for him, was the only way to raise the cultural level of the people.

Undoubtedly one of the most difficult aspects of vulgarizing and popularizing an Aristotelian text was the fact that vulgarizers were typically highly cultured intellectuals who had to adopt the point of view of the common person in order to see how best to make philosophical content more accessible. The "lower standpoint" was in fact rarely adopted: intellectuals still wrote as intellectuals, not as common people, but this does not mean that they did not want to popularize or vulgarize knowledge, and that there were such instances of empathy cannot be ruled out. It means simply that they were unable to write in a register that differed from the elevated manner to which they had been accustomed through education. The study of linguistic register is therefore useful only in determining whether a text was easy or difficult to understand; ${ }^{91}$

88. Biblioteca Nazionale, Napoli, Ms. V D 45, f. 70r.

89. Biblioteca Nazionale, Napoli, Ms. V D 45, f. 70v.

90. Robortello, De artificio dicendi, $15 \mathrm{v}$.

91. Alessio Cotugno's seminal investigations show how the accessibility of a text depends on the various linguistic registers that are used. He clearly proves that Piccolomini's works on Aristotle's poetics employed a more accessible register than Castelvetro's Poetica. See Alessio Cotugno, "Piccolomini e Castelvetro traduttori della 'Poetica' (con un contributo sulle modalità dell'esegesi aristotelica nel Cinquecento," Studi di lessicografia italiana, 23 (2007): 113-219; Alessio Cotugno, "Le 'Annotationi' di Piccolomini e la 'Poetica' di Castelvetro a confronto: tecnica argomentativa, vocabolario critico, 
however, it provides no basis for arguing that there could be no intentional public because the language was too complex.

This should alert us to the dangers of thinking that the culture of the people and the culture for the people are one and the same; ${ }^{92}$ that is to say, conflating a series of cultural practices that originate with the people and a type of knowledge produced for them by the educated classes, as in the case of the vulgarization and popularization of knowledge. ${ }^{93}$

Vulgarizations were for the most part, if not always, the work of cultured individuals, and their readers might of course include men and women who were capable of reading even the most complex works in Latin, not only "idiots" or "illiterates." It is therefore wrong to identify them with popular works associated with a particular group of readers. ${ }^{94}$ Likewise it is erroneous to attribute an elevated linguistic register to an elevated audience, especially in light of explicit statements made by an author regarding a lower-level public and in view of the fact that the ultimate aim of these intellectuals was to instruct. ${ }^{95}$

Hence this whole process of "democratizing" knowledge is to be understood as an extension of knowledge through the vernacular in opposition to

dispositivi esegetici," in Forms of Conflict and Rivalries in Renaissance Europe, ed. David A. Lines, Marc Laureys, and Jill Kraye (Göttingen: V\&R Unipress / Bonn University Press, 2015), 161-206. In particular, his methodology of research on the management of information may in time reveal in detail the complexity of the text. See Cotugno, "Piccolomini e Castelvetro traduttori della 'Poetica," 180 . He correctly argues that complexity can stand in the way of a text's readability, but it cannot be used as evidence to affirm that these texts were directed at a higher public than intended.

92. Carlo Ginzburg, Il formaggio e i vermi (Torino: Einaudi, 1976), xv.

93. Roger Chartier, Lectures et lecteurs dans la France d’Ancien Régime (Paris: Seuil, 1987), 7-17.

94. Contrary to the commonly held view that vernacular books were written for the lower classes and therefore reflected their tastes (such was the fate, according to Ginzburg, of Mikhail Bakhtin in Rabelais and His World), evidence shows that the most successful works were "not those written for the lower classes, but those that were written for different groups of readers." See Eisenstein, 63. On this question, Chartier writes that "it is pointless to try to identify popular culture by some supposedly specific distribution of cultural objects. Their distribution is always more complex than it might seem at first glance, as are their appropriations by groups and individuals" (Chartier, "Culture as Appropriation," 233).

95. As Roger Chartier correctly argues concerning the story of the miller Domenico Scandella narrated by Carlo Ginzburg, "the books he read were in no way especially designed for a popular audience" (“Culture as Appropriation," 233-34). Of course, Chartier points out, common people "did not, by any means, read everything read by the notables but the books they acquired were not specific to their class" (240). 
the Latin-based culture to include a broader social base and therefore a greater number of people. We are still a long way from the mass knowledge or culture of today, of course, but we are looking at knowledge that reaches diverse social strata and therefore expands the number of cultural consumers.

However one looks at it, vulgarization is a "downwards movement" that exemplifies the complexity of connections and exchanges of knowledge that took place among "low," "medium," and "high" culture, or at least between different social and cultural classes. The vernacular language was never used innocently, but at least in the Renaissance it often accompanied a desire to transmit and disseminate knowledge, especially concerning philosophical and scientific texts. The "downwards movement," or the attempt to make the content of knowledge accessible to a greater number of people, may in fact be considered an initial phase in a process whose ultimate goal was to generate a subsequent "upwards movement" with the creation of a culture and an intellectual interest that had not existed until that time. This is borne out by Oreste Vannocci Biringucci's already mentioned Lettera ai lettori to the Sopra le Mechaniche d'Aristotele, ${ }^{96}$ in which the explicitly stated purpose is to facilitate knowledge, make it public, and ensure that "good minds are put on a par with uncouth minds, and those who are notable and important with those who are low-caste and plebeian." ${ }^{97}$ This leads us to the conclusion that even complicated and highly elaborate linguistic works of vulgarization such as Castelvetro's were not symptomatic of a closure of knowledge or a restriction of the audience, but were in fact an attempt to improve the knowledge of those who had no classical education, or were more comfortable reading in their own native tongue. ${ }^{98}$ This was a clear indication that the vernacular was ripe for tackling involved speculative and theoretical questions, as well as taking on the role of a language of culture and an instrument of emancipation. ${ }^{99}$

96. The work was published in 1547 in Latin, in his own words much to the regret of Biringucci, with the title In mechanicas quaestiones Aristotelis paraphrasis paulo quidem plenior.

97. Piccolomini, Sopra le Mechaniche d'Aristotele, 4.

98. The same applies today when teaching philosophy to those who have no concept of the discipline. As with the vulgarizers, the content is not trivialized, nor is the register lowered, but strategies are sought that will clarify the meaning. To trivialize knowledge when the purpose is to increase it would be a job badly done indeed.

99. Cotugno clearly shows that some vernacular works used a linguistic complexity similar to those written in Latin, just because the vernacular aimed to supplant Latin as a language of culture. The elevated 


\section{A new conception of knowledge for all}

Although Latin was still the main language of scientific and erudite discourse in the Renaissance, the vernacular was already taking its first steps towards asserting "its own dignity and capacity for expressing even the most abstruse philosophical concepts," ${ }^{\prime 100}$ making them accessible to people. In his Dialogo delle lingue (1542), Sperone Speroni sought to transform the vernacular into a language of philosophy and science that would eventually supplant Greek and Latin even in erudite circles, and therefore become the vehicle for the transmission of knowledge. Contrary to what some fourteenth- and fifteenth-century humanists believed, Speroni asserted that knowledge of Greek and Latin was not necessary to understanding Aristotle, and even that "the study of Greek and Latin is the cause of our ignorance." ${ }^{101}$ Thus, he claims,

May God will it that for the benefit of those who will come after me all the books of all the sciences, as many as can be counted in Greek and Latin, some scholarly and generous person dedicate himself to rendering into the vernacular, so that the number of good philosophers would be greater than it is now, and their excellence rarer. ${ }^{102}$

\footnotetext{
linguistic register is explainable also by this process of substitution of one language with another; while the fact that the intended public was higher than what this intellectual, whose aim was to improve knowledge, explicitly stated, does not constitute a clue. See Alessio Cotugno, "Osservazioni linguistiche sull' 'Instrumento della filosofia' di Alessandro Piccolomini (1551). Testualità, lessico, procedimenti espositivi," in "Aristotele fatto volgare": Tradizione aristotelica e cultura volgare nel Rinascimento, ed. D. A. Lines and E. Refini (Pisa: ETS, 2015), 99-148.

100. Tullio Gregory, Origini della terminologia filosofica moderna. Linee di ricerca (Florence: Olschki, 2006), 72 ,

101. Sperone Speroni, Dialogo delle lingue (Pescara: Libreria dell'Università, 1999), 188. On this "revolutionary" conception, see Cesare Vasoli, "Sperone Speroni: La filosofia e lingua. Lombra del Pomponazzi e un programma di volgarizzamento del sapere," in Il volgare come lingua di cultura dal Trecento al Cinquecento, ed. Arturo Calzona, Francesco Paolo Fiore, Alberto Tenenti, and Cesare Vasoli (Florence: Olschki, 2003), 342.
}

102. Speroni, Dialogo delle lingue, 184: "Dio volesse in servigio di chi verrà dopo me, che tutti i libri dogni scientia quanti ne sono greci, et latini, alcuna dotta, et pietosa persona si desse a render volgari, che per certo il numero de i boni philosophanti sarebbe più spesso, che egli non è, et più rara diverrebbe la loro excellentia." The mimetic nature of Speroni's text makes it difficult to attribute any particular position to the Paduan intellectual, but when we compare it to other texts, and above all to the manner 
Speroni looks forward to the day when "of every thing in every country I may speak every language," and the sciences and arts shall no longer be under the dominance of the classical languages. ${ }^{103}$ Yet his ambition goes further still. He hopes

[...] through reason to be capable of communicating to others their affections and their own doctrine, with their own language, therefore to translate the philosophy sown by our Aristotle in the fields of Athens from Greek into the vernacular, be it Italian or German, which would not be like throwing it among the stones in the woods where it would become infertile, on the contrary it would make something distant close, something foreign a citizen of all provinces $[\ldots]$ in this way the Peripatetic speculations would become far more familiar to us, and domestic such as they are not at present, and they would be easier to treat, and would be understood by us if some learned man should translate them from Greek into the vernacular. ${ }^{104}$

Speroni believes that all the languages of the world can signify and express philosophical matters, but he also recognizes that it is still expedient to discuss science in the classical languages simply because it is still customary to do so. This, however, does not mean that philosophy cannot be discussed in Mantuan or Milanese. ${ }^{105}$ Philosophy should not be ashamed of being expressed in Lombard rather than Greek or Latin words; indeed, it "does not disdain to find its place

in which it was received, the most cogent perspective appears to be the one espoused by Scolare in reporting the arguments of Pomponazzi. The same opinion is held by Mario Pozzi, in Trattatisti del Cinquecento (Ricciardi: Milan, 1978), 619.

103. Speroni, Dialogo delle lingue, 188.

104. Speroni, Dialogo delle lingue, 192: “[...] poter di ragione comunicare con altrui gli affetti, et la dottrina di sé, con la sua lingua medesma, dunque tradurre la philosophia seminata dal nostra Aristotele ne i campi d'Athene, di greco in volgar, italiano, o tedesco, non serebbe gettarla tra' sassi ne i boschi, ove sterile divenisse, anzi sarebbe far lei di lontana propinqua, et di forestiera cittadina d'ogni provincia ... così le speculationi peripathetice ci diverrebbono assai più familiari, et domestice che non sono al presente, et più facilmente si tratterebbono, et intenderebbono da noi se di greco in volgar alcun dotto homo le convertisse."

105. Speroni, Dialogo delle lingue, 194. 
in the minds of Lombards," ${ }^{106}$ just as it did not disdain to be manifested among common people who had no knowledge of Greek or Latin.

After Speroni, the vernacular "was perceived increasingly as the vehicle for disseminating philosophy and the sciences beyond the schools and conquering a different public, but above all for overcoming the restrictions and limitations of the traditional culture upheld by scholastic Latin." ${ }^{107}$ This is not merely a question about the legitimacy of the vernacular as a language of culture, since the vernacular itself has now acquired value "as an instrument of emancipation and cultural innovation." 108 The case of Galileo Galilei offers us a clear picture of how intellectuals viewed the vernacular language. Aware as he was that the vernacular was more limiting than Latin in terms of the international reach of his ideas, he nevertheless believed that Italian would someday become a language of culture, and in any case wished to "distance himself in protest from the erudite caste." ${ }^{109}$ It was at this time that the defence of the vernacular language rested upon the newfound awareness that any culture is above all an ongoing transmission of prior experiences that lead, when transferred to other contexts, to transformations in all areas of knowledge. At a time when the official knowledge of the Church and the universities was perceived to be stagnating, it was "the vernacular, not Latin, that opened up new cultural horizons." 110

As we have seen, Aristotle's vulgarizers and members of reformist circles shared the notion of the vernacular as the new language of culture and principle of emancipation from authority, often becoming identified with one another in the process. Two cases may serve here to illustrate that these movements were not only coeval, but also deeply entwined and united by the idea of spreading knowledge beyond the class of university intellectuals and the clergy.

106. Speroni, Dialogo delle lingue, 200. Another participant in the dialogue finds it abhorrent to "see Aristotle's philosophy written in the Lombard language and hear it being discussed by all manner of uncouth people, porters, peasants, boatmen, and other such people."

107. Gregory, 72.

108. Gregory, 72.

109. On Galileo's conception of the vernacular, see Marazzini, Storia della lingua italiana. Il secondo Cinquecento e il Seicento, 58. On Galileo's conception of knowledge, see Nick Wilding, Galileo's Idol: Gianfrancesco Sagredo and the Politics of Knowledge (Chicago: University of Chicago Press, 2014).

110. Gregory, 72. 
The first is the case of Antonio Brucioli. The problem for Brucioli went far beyond the debate about the legitimacy of vulgarizing Holy Scripture or Aristotelian texts: ${ }^{11}$ his objective was to make the truth available to all people. ${ }^{112}$ As he writes in the dedicatory letter to King Francis of France in his translation of the New Testament,

And to those who piously say that it is dangerous to put this light before common eyes because it contains difficult and dark things, which the simple people are not given to understanding and therefore risk being led astray, I shall say first of all that they should take the matter up with the Holy Spirit, who wanted to reveal these high secrets to simple people and idiots, judging them to be more worthy because their heads were not cluttered with worldly wisdom. ${ }^{113}$

Vernacular translations are not only important, therefore, but also a duty, because otherwise there would be no way of explaining why Christ "sent the Holy Spirit to make illiterate men speak and be understood in all languages." ${ }^{114}$ The vernacular for Brucioli is therefore the medium through which to reveal to the people all those secrets which Latin, Greek, and Hebrew keep hidden. Brucioli attacks those in the upper classes who withhold power by preventing the circulation of knowledge and the understanding of the truth. As the passage above goes on to assert:

111. Franco Pierno has shown that Brucioli applied his conception even to Boccaccio's Decamerone; see Franco Pierno, "Il modello linguistico decameroniano e il suo rapporto con il volgare nel pensiero di Antonio Brucioli," Cahiers d'études italiennes 8 (2008): 99-114.

112. Almost all the following passages from Brucioli's writings have been examined by distinguished scholars like Paolo Simoncelli, Massimo Firpo, and Gigliola Fragnito, but they have never been related to the vulgarization of Aristotle.

113. Antonio Brucioli, La Biblia (Venice: Giunti 1532), dedication: "Et a quegli che dicono sotto specie di pietà ch'egli è cosa pericolosa a mettere questa luce avanti agli occhi de' vulgari per esservi cose difficili et oscure, le quali le semplice genti non possono così bene comprendere et che potrieno essere causa di fargli errare, dico primieramente che questi tali contendino con lo spirito santo, che volle a' semplici et idioti manifestare quegli alti secreti, giudicandone quegli più degni non havendo le menti gonfiate di mondana sapientia."

114. Brucioli, La Biblia, dedication. 
[...] I say that the difficult and dark things are few, and pose no threat to simple minds, for whom it is an easy matter to defer to others when they do not understand something, unlike the Greek and Latin men, for whom the dangers have always been far greater and far more serious, because maligning they have wanted to know more than was necessary, because those passages that are so fraught with difficulty and danger have never led anyone astray except those who because of languages and scientific knowledge have thought of themselves as important, and because of them have wanted to prove themselves to be more knowledgeable than others, and hence have fallen into real shadow. ${ }^{115}$

In the dedication to Renata, Duchess of Ferrara, in his I sacrosanti libri del vecchio testamento, Brucioli declares that he has undertaken the translation of the Bible

Prompted by those who, erring grievously, declare it not to be a good thing that Holy Scripture should exist in our vernacular, and through it be expressed so that it may become known to all, saying that in this manner divine speech is brought to vulgar ears [...] these enemies of the divine word [...] say that things lose their credibility and venerability to the extent that they are known by many, and many are allowed to participate, and these wise fools of the world are unaware that those things that appear great, and of greatest benefit to us, the more they are inquired into, and the more common they become, and widely known, the more their reputation and venerability will grow, yet just as the truth is the opposite of falsehood, [...] so they proceed, and just as falsity always seeks to remain hidden, and truth to reveal itself, so too do false religions seek to conceal themselves and cover themselves as much as possible with terrors and the veils of ceremony, hiding their own truths from view, but that

115. Brucioli, La Biblia, dedication: "[...] dico che poche sono, et di nessuno pericolo a le semplici menti [le cose difficili et oscure], le quali facilmente si rimettono a altri in quelle cose che esse non intendono, ma bene di maggiore et più grave pericolo sono state sempre a gli huomini Greci, et Latini, che hanno malignando voluto sapere più di quello che bisogna sapere, perché que' luoghi che allegheranno questi di difficultà, et pericolo, non si truova che conducessino a mala via se non quegli che per le lingue, et scientie, hanno pensato di essere qualche cosa, et da quegli presa la occasione volsono mostrare di sapere più che gli altri, et caddono in manifeste tenebre." 
which is true wants, unlike that which is false, to be manifest to all, known by all, so that the good that it brings may be seen clearly, and may lift us all out of falsehood, so that the greater the number of those who gain knowledge of it, the more its glory shall grow, and the greater and better its fruit shall be. ${ }^{116}$

Truth and knowledge could not be concealed, but needed revealing to as many people as possible to bear the best fruit. Brucioli had already dwelt at length on this problem in 1532 in the Biblia, where he writes to Francis I:

\begin{abstract}
Some will perhaps exclaim that it is unworthy for a woman or a cobbler to discourse on Holy Scripture, and should understand them through reading, when it is better to understand them in the simplicity of the heart than in the elevation of science, and to hear speak of the virtue of the spirit to similar simple idiot souls than certain grand masters who with their well-founded philosophy sully the word of God. [...] Do we want to hide this evangelical light from those devout and simple minds who wish to see it, as if it had been sent from heaven just for the educated? ${ }^{117}$
\end{abstract}

116. Antonio Brucioli, I sacrosanti libri del vecchio testamento, vol. 1 (Venice: Zanetti, 1540), dedication: "mosso da quegli, che grandemente errando, dicano non essere ben fatto, che essa divina scrittura sia nella nostra lingua vulgare, \& in essa dichiarata, talmente che possa essere nota a ciascuno, dannando, che così si mettino agli orecchi del vulgo i parlari divini [...] questi adversarii del verbo divino [...] dicano che le cose tanto perdano di riputazione, \& venetratione quanto più sono note a assai, \& che assai ne sono fatti partecipi, non si accorgendo questi stolti sapienti del mondo, che quelle cose che sempre appaiono maggiori, \& di maggior frutto alla nostra salute, quanto più si ricerca quali esse sieno, \& quanto più sono communi, $\&$ da più conosciute, più crescano di nome $\&$ di reverentia, ma come la verità è contraria alla falsità, $[\ldots]$ così per contrario modo fra loro procedono, \& come la falsità sempre cerca di stare occulta, \& la verità farsi palese, così le false religioni cercano di occultarsi, et coprirsi quanto sia loro possibile, sotto terrori, \& velami di ceremonie, fuggendo l'esserne ricercata la verità, ma la vera vuole essere, per contrario modo dalla falsa, a tutti palese, da tutti conosciuta, accio che si vegga il bene che essa apporta, \& levi ogniuno dalla falsità, in modo che quanti più ne hanno la cognitione, più ne viene grande la gloria sua \& maggiore, \& migliore il suo frutto.”

117. Brucioli, La Biblia, dedication: "Esclameranno forse alcuni essere indegna cosa che una donna, o uno calzolaio, parli de le sacre lettere, et quelle intenda leggendo, quando meglio è intenderle in semplicità di cuore, che in elevazione di scientia, et udire parlare a simili anime semplici idiote de la virtù de lo spirito che certi sommi maestri, che con la loro sana philosophia maculano la parola di Dio. [...] vogliamo ascondere questa luce evangelica a le devote e semplici menti, che desiderano di vederla come se per i soli litterati fusse mandata dal cielo?" 
In Brucioli's view, therefore, everyone has access to truth and the sciences because they were given to us to be "understood by the pious and modest idiot as much as by the arrogant philosopher." ${ }^{118}$ Culture is therefore just as available to "the blind, the lame, the beggar, the publican, centurions, sappers, women, and children," as to "the merchant, the blacksmith, the farmer, the builder, the fisherman, the publicans, and all the conditions of men, and women." 119 In the "communication of truth" there must be "no difference between people, ages, bodies, or circumstances," because knowledge is God-given. ${ }^{120}$ Brucioli includes the philosophical vulgarizations of Plato and Aristotle in the transmission of truth: ${ }^{121}$

And if this divine knowledge in one and the other testament, and in Plato and Aristotle, and in all the others, was written in those languages that were spoken at that time, if now they are not spoken, why then should these truths not be read in the languages that are in use now, and therefore understood by more people, since the benefit is greater the more people participate in it. ${ }^{122}$

The ultimate aim for Brucioli, as for the other Aristotelian vulgarizers, was to facilitate the acquisition of knowledge in as many people as possible. With this purpose in mind, he embarked upon the translation of a sizeable portion of the Aristotelian corpus, and in the time-span of twelve years published La Rettorica d'Aristotile tradotta con la sposizione di Rocco Catanio (1545), Gli otto libri della Republica che chiamono Politica di Aristotile (1547), La Phisica di Aristotile (1551), Aristotile della generatione et corrutione (1552), De celo et mondo (1552), La meteora (1555), Di Aristotile libri tre dellanima (1557).

118. Brucioli, La Biblia, dedication.

119. Brucioli, La Biblia, dedication.

120. Brucioli, La Biblia, dedication.

121. Brucioli, La Biblia, dedication.

122. Ibid.: "Et se questa divina scientia de l'uno \& l'altro testamento, \& la Platonica, \& l'Aristotelica, \& tutte le altre, in quelle lingue furno scritte, che all'hora si parlavono, se hora più naturalmente non si parlano, perché non si debbe leggere questa verità in quelle lingue che sono in uso, \& da più intese, essendo uno bene tanto maggiore, quanto da più è partecipato." 
The second case, no less important than the first, is that of Giovan Battista Gelli. ${ }^{123}$ The son of a modest artisan, Gelli never translated any Aristotelian works into Italian, but he was a skilful vulgarizer of Aristotelian ideas in philosophical dialogues that bordered on heresy. The importance of his work in this context rests on the direct link he established between the methods used to vulgarize Holy Scripture and those adopted with the works of Aristotle. In I capricci del Bottaio (1546), Gelli develops the Speronian idea that "it is not languages that make men cultured, but the sciences, and one learns languages in order to gain knowledge of the sciences they contain." 124 The knowledge of sciences is not a direct consequence of the knowledge of languages, and many who know Greek and Latin may not have any understanding of the sciences. Knowledge, whether transmitted in the vernacular or in one of the classical languages, comes with "great effort." Learning the classical languages before embarking upon the acquisition of knowledge only adds to the effort, hence, if all the sciences were already written in one's native language, a man "would not have to spend four to six of his best years learning a language only to use it to move on to studying the sciences." 125 Like Sperone Speroni and Alessandro Piccolomini, Gelli viewed the fact that the sciences were written in Latin or Greek as an obstacle to the advancement of knowledge. The problem therefore is to understand why the "literati are so hostile towards those who translate something" into the vernacular. ${ }^{126}$ These so-called literati seem to think that the vernacular is not suitable for translating such elevated matters as Holy Scripture

123. On Gelli, see Armand L. De Gaetano, Gianbattista Gelli and the Florentine Academy: The Rebellion against Latin (Florence: Olschki, 1976); Vittoria Perrone Compagni, "Cose di filosofia si possono dire in volgare. Il programma culturale di Giambattista Gelli," in Il volgare come lingua di cultura dal Trecento al Cinquecento, ed. Arturo Calzona, Francesco Paolo Fiore, Alberto Tenenti, and Cesare Vasoli (Florence: Olschki, 2003), 301-37; Eva Del Soldato, "Aristotelici, accademici ed eretici. Simone Porzio e Giovan Battista Gelli," in Simone Porzio, An homo bonus vel malus volens fiat (Edizioni di Storia e Letteratura: Rome, 2005), v-xxix; Chiara Cassiani, Metamorfosi e conoscenza. I dialoghi e le commedie di Giovan Battista Gelli (Rome: Bulzoni 2006); Anna Laura Puliafito, Volgarizzamento e propaganda: Giovan Battista Gelli e l'Accademia fiorentina, in Mecenati, artisti e pubblico nel Rinascimento, ed. L. Secchi Tarugi (Florence: Cesati, 2009), 640-55; Anna Laura Puliafito, "Filosofia, letteratura e vita civile: Giovan Battista Gelli e il volgare," Modernidades 11 (2011), 1-15.

124. Gelli, 195.

125. Gelli, 198.

126. Gelli, 200. 
or philosophy because it detracts from their "reputation." 127 But this is not an adequate explanation in Gelli's view, since "all languages [...] are capable of expressing the concepts and needs of those who speak them." ${ }^{128}$ The real reason is another, and it is quickly stated: "the accursed jealousy and desire they have to be viewed as better than others." ${ }^{129}$ Gelli goes on to support his thesis with a fictional dialogue that shows how the intellectuals of the time viewed vulgarization as a democratization of knowledge that was aimed primarily at those who did not know the classical languages:

I recall finding myself recently in the presence of certain literati, one of whom said that Bernardo Segni had translated Aristotle's Rhetoric into the vernacular, to which another replied that he had performed a great disservice; and when asked why, he said: "Because it is not good that every uneducated person should be allowed to know what another has acquired over many years with great effort from Greek and Latin books. ${ }^{130}$

Gelli is openly critical of this miserly approach to knowledge, writing that these are "inappropriate words [...] not [...] only for a Christian, but also for any human being!" 131 The desire to keep knowledge under wraps is not only anti-Christian, therefore; it is in fact contrary to the very nature of the human being, whose task is to "love all and help others [...], the greatest gift to whom is to aid their understanding." ${ }^{132}$ Hence Gelli believes "that there is nothing more useful and praiseworthy" than translating into the vernacular that which is most necessary, namely the precepts of religion and the principles of philosophy. If it were

127. Gelli, 201.

128. Gelli, 201.

129. Gelli, 201.

130. Gelli, 201: "io mi ricordo che ritrovandomi a questi giorni dove erano certi litterati, e dicendo uno che Bernardo Segni aveva fatto volgare la Retorica d'Aristotele, uno di loro disse che egli aveva fatto un gran male; e domandato della ragione, rispose: "Perché e' non istà bene ch'ogni volgare abbia a sapere quello che un altro si arà guadagnato in molti anni con gran fatica su pe' libri greci e latini." On the importance of Segni as a translator of Aristotle, see David A. Lines, "Rethinking Renaissance Aristotelianism: Bernardo Segni's Ethica, the Florentine Academy, and the Vernacular in SixteenthCentury Italy," Renaissance Quarterly 3 (2013): 824-65.

131. Gelli, 201.

132. Gelli, 201 
possible to start acquiring them in childhood, men would "more devoutly love and defend the teachings of the Christian religion." ${ }^{133}$ Gelli goes on to say that "Christians who teach their children to read with mercantesca or legends where there is nothing to learn should be ashamed." ${ }^{134}$ He believes that rote learning the Latin words of sacred and philosophical texts without understanding their content "is like women croaking or parrots chirruping." ${ }^{135}$ The end purpose of vulgarizers such as Gelli is not only the dissemination of knowledge, therefore, but also making knowledge available to all human beings, who must therefore understand and absorb the message conveyed by religion and philosophy. The democratization of culture is part of a wider conception according to which the accumulation of knowledge is a form of progress that allows human beings to avoid mistakes caused by ignorance. ${ }^{136}$ Preserving culture in the classical languages is an aristocratic paradigm that is inhuman and therefore must be opposed at all costs. Gelli openly attacks the supporters of this aristocratic conspiracy to prevent the vernacular from becoming a language of culture, pointing to

the miserliness of the priests and friars who, not content with their part of tithes God ordered be allocated to them by law, and wanting to live as sumptuously as they do, they keep hidden from us, selling them to us bit by bit, or piecemeal, in so doing terrorizing men with a thousand false threats that are not written in the law as they interpret them; so that they have snatched from the hands of the poor more than half of what they had $[\ldots]$ this is an evil that I feel resides not only in the priests, but in everyone: indeed there is not a man who does not think of taking money from the possessions of others and keeping it as his own. It is true that the priests, friars, and notaries, who do it with words, are better at it than others. [...] it would not be so easy for them [to deceive] if men had better knowledge of Holy Scriptures than they have. And the reason why human affairs are not translated is likewise the impiety of many doctors and lawyers who want to sell us common things; and in order to so, they have come up with this artful ruse whereby contracts cannot be written in the vernacular, but only 
in their own polished grammar, which they only partly understand and others not at all. I am astonished that men have tolerated such conditions, under which it is possible to perpetrate a thousand deceptions. ${ }^{137}$

Priests and friars, or members of the Church generally, along with lawyers and jurists, have conspired against the opening up of culture in order to preserve the privileges of their caste and exert control over the uneducated classes. ${ }^{138}$ This is a harsh indictment of the political and religious establishment, the subversiveness of which did not escape the notice of the censors who forced him to make substantial amendments to the more controversial passages. ${ }^{139}$ Gelli's position here is reminiscent of the words uttered by the miller Domenico Scandella who, when sentenced to death by the Inquisition, said, "speaking Latin is a betrayal of the poor because in lawsuits the poor do not know what is being said and are crushed; and if they want to say four words they need a lawyer." ${ }^{140}$ The use

137. Gelli, 205: “[del]l'avarizia de' preti e de' frati, che non bastando loro quella porzione delle decime che avevano ordinato loro Iddio per legge, a voler vivo tanto suntuosamente come e' fanno, ce le tengono ascose, e ce le vendono a poco a poco, come si dice a minuto, e in quel modo però che e' vogliono, spaventando gli uomini con mille falsi minacci, i quali non suonan così nella legge come egli interpretano; di maniera che egli hanno cavato di mano a’ poveri secolari più che la metà di quel che egli avevano [...] questo è un male che mi pare che si dia non solamente a i sacerdoti, ma ognuno: anzi non cè uom che pensi ad altro, se non in che modo e' potesse cavare e danari delle scarselle d'altri, e mettergli nella sua. Egli è ben vero che i preti, e frati e i notai, che lo fanno con le parole, son più valenti de gli altri. [...] non sarebbe venuto lor fatto così agevolmente [ingannare], se gli uomini avessino avuto più cognizione delle Scritture Sacre che e' non hanno. E la cagione che non si traducono l'umane è similmente la impietà di molti dottori e avocati, che ci voglion vendere le cose communi; e per poterlo far meglio, hanno trovato questo bel ghiribizzo, che i contratti non si possin fare in volgare, ma solamente in quella loro bella grammatica, che la intendon poco eglino e manco altri. Io mi meraviglio, che gli uomini abbin mai sopportato tanto una cosa simile sotto la quale si può fare mille inganni."

138. Gelli's critique cuts deeper than this, though: the only reason why men do not criticize the religious authorities is because they do not know the Holy Scriptures. Yet, as Christians, all human beings are equals and can therefore criticize and judge both priests and princes, and even point out the mistakes that the pope himself "commits as a man and as a Christian" (Opere, 206). Gelli’s position is extreme and comes close to the anti-papal views of the Lutherans.

139. Andrew L. De Gaetano, "Tre lettere inedite di G.B. Gelli e la purgazione de 'I capricci del bottaio," Giornale storico della letteratura italiana 134 (1957): 298-313.

140. Ginzburg, 12: "Io ho questa opinione, che il parlar latin sia un tradimento de' poveri, perché nelle litte li pover'homini non sano quello si dice et sono strussiati, et se vogliono dir quatro parole bisogna haver un avocato." 
of Latin by the upper classes was seen by the vulgarizers as a means of controlling and exerting power over those who had only limited access to culture. The vernacular language was therefore perfectly placed to express the most complex ideas and to emancipate the people from the dominance of the educated classes, under whose yoke they had laboured for centuries. It is in this double sense, therefore, that the project to democratize knowledge for the people becomes vitally important; and it is in this sense, too, that we can speak of an Aristotle for the people.

The overall relationship that was established between Aristotle and the people in the Renaissance thanks to vulgarization is captured in the letter to Aristotle written by Alexander the Great, which is contained in Plutarch's Parallel Lives. ${ }^{141}$ The Macedonian king criticizes his teacher for having broadcast the knowledge that had once been the prerogative of a few among the common people and his enemies. References to this anecdote are to be found in the works of a number of vulgarizers, including Brucioli in his preface to the translation of Aristotle's De generatione et corruptione. The most interesting reading of the letter, however, comes from Antonio Tridapale dal Borgo, a modest mid-sixteenth-century intellectual whose only claim to fame is the fact that he published the first vernacular logic. ${ }^{142}$ Tridapale shows that underlying Alexander's criticism was the notion that knowledge was a form of power that dissipates once it enters the public domain. The question of whether it was right for knowledge to have been the exclusive preserve of a small group of people for so long if it leads to power and domination over others was a pressing concern for vulgarizers. Tridapale, like Gelli, Brucioli, and many other vulgarizers from the same period, was clear on this point: knowledge must be available to all; therefore, in order to reach as many people as possible, it must be written in the vernacular as well as Latin. Alexander the Great's desire to keep all knowledge for himself and thereby maintain his power over other men is therefore inhuman. As we have seen, if, as Aristotle asserts, all human beings tend naturally towards knowledge, denying them access to knowledge is an inhuman endeavour. For this reason, Tridapale, Gelli, and many others state that the highest ambition is not to conceal all knowledge from the greater part of men, but on the contrary to help

141. Marianne Pade, The Reception of Plutarch's Lives in Fifteenth-Century Italy (Copenhagen: Museum Tusculanum Press, 2007), 52.

142. Antonio Tridapale dal Borgo, La loica in lingua volgare (Venice: Gherardo, 1547), 2r; Marco Sgarbi, The Italian Mind: Vernacular Logic in Renaissance Italy (Leiden: Brill, 2014), 127-53. 
others gain knowledge of those things that nature has made available to us all, even revealing the most difficult and arcane secrets. Hence the need to translate Aristotle into the vernacular for the people.

Communication and the spread of knowledge are a value for Aristotle's vulgarizers, and its defence requires a transvaluation of the values that had accompanied culture up until that moment. Knowledge is no longer perceived as predominantly closed, aristocratic, partly "tied to a vision of the world and history that belonged to hermeticism," ${ }^{143}$ Pythagoreanism, Platonism, and Christianity; it is now more open, "democratic", and "egalitarian," and seems closer to the conception of the thinkers who vulgarized Aristotle's works. While it is important to avoid over-generalizing, it is nevertheless the case that, in terms of opening up knowledge, Aristotle's vernacular works display some of the qualities that are later to be found in some aspects of "modern science."

For a long time in the Middle Ages, and later into the Renaissance period, the man of learning was viewed as something akin to a magician who has the power to penetrate the inner workings of an infinitely complex reality, the secrets of which had to be kept hidden from the common people to avoid its debasement. ${ }^{144}$ Remember the words of Cornelius Agrippa von Nettesheim: "any experience of magic holds the public in contempt, wants to be hidden, builds its strength in silence, and is destroyed when broadcast." 145 Thanks primarily to Aristotle's vulgarizers, but also scientists like Galileo Galilei, secrecy in Renaissance Italy generally became an anti-value, whereas sharing and opening up knowledge became a moral imperative. ${ }^{146}$ Although magic, philosophy,

143. Paolo Rossi, La nascita della scienza moderna in Europa (Rome-Bari: Laterza 1997), 19. For an accurate description of the problem see Vittoria Perrone Compagni, "Parlare velato: trasmissione esoterica della verità nel Rinascimento," in La verità in scrittura, ed. Fabio Bazzani, Roberta Lanfredini, and Sergio Vitale (Florence: Clinamen, 2013), 73-86.

144. In the Gospel of Matthew, 7, 6 we read: "give not holy things to dogs nor cast not your pearls before swine, or they will trample them under their feet and turn and tear you to pieces."

145. Cornelio Agrippa, Opera Omnia, vol. 1 (Lyon: Bering, 1550?), 498.

146. On the concept of "openness of knowledge," see William Eamon, "From the Secrets of Nature to Public Knowledge: The Origins of the Concept of Openness in Science," Minerva 23 (1985): 321-47; William Eamon, "From the Secrets of Nature to Public Knowledge" in Reappraisals of Scientific Revolutions, ed. David C. Lindberg and Robert S. Westman (Cambridge: Cambridge University Press, 1990), 333-66; Pamela O. Long, "The Openness of Knowledge: An Ideal and Its Context in 16thCentury Writings on Mining and Metallurgy," Technology and Culture 2 (1991): 318-55; Pamela O. 
and science in the Renaissance are hopelessly entangled, ${ }^{147}$ in terms of modern historiography, their approach to knowledge could hardly be more different. Aristotle's vulgarizers are closest to the ideal conception of knowledge of "modern science," and we might even say they were its most immediate and fertile precursors. Those who criticized Alessandro Piccolomini for his vulgarizations, which perforce appeared to be directed at "uncouth" people and "people devoid of judgment" were reminded by him of the distinction between intelligent people without access to culture who needed educating and people who were completely uninterested in knowledge and devoid of any capacity for critical thought, who were therefore unsuitable as recipients for his works:

And they are greatly deceived if they think that those who read my works are uncouth and so devoid of judgment that they assume that with the same amount of concentration and immediacy of understanding that is required to read fables and romances, they can tackle matters astrological and scientific, almost as if writing in our language necessarily entailed giving the same degree of clarity to all subjects. Be it not pleasing to God that such ill-fortune should befall this work that it should fall into the hands of such uncouth and inept readers that believe such things. ${ }^{148}$

Piccolomini's critique is double-edged: those who presume to read scientific works in the vernacular as if they were fables are uncouth and inept, but those who believe that vulgarizations are of a low cultural and doctrinal order just because they are not written in Greek or Latin are even more so. For Piccolomini, as for many other contemporary vulgarizers, it is absolutely clear

Long, Openness, Secrecy, Authorship: Technical Arts and the Culture of Knowledge from Antiquity to the Renaissance (Baltimore: Johns Hopkins University Press, 2001), 175-243.

147. Brian Vickers, "Introduction," in Occult \& Scientific Mentalities in the Renaissance, ed. Brian Vickers (Cambridge: Cambridge University Press, 1984), 1-55; Paolo Rossi, Il tempo dei maghi. Rinascimento e modernità (Milano: Raffaello Cortina, 2006), 103-29.

148. Piccolomini, La prima parte dele theoriche overo speculationi dei pianeti, A1": "e si ingannano di gran lungi, se pensano che le persone che son per leggere li scritti miei, sieno si rozzi, \& privi d'ogni giuditio, che si stimino, che con quella medesima attenzione, \& subita apprensione, con la quale si leggano le favole, \& le novelle, con la medesima si devin leggere le materie astrologiche, \& scientifiche cosi fatte, quasi che lo scrivere in lingua nostra habbia de porgere ugualmente ad ogni materia ugual chiarezza. Non piaccia a Dio che con si mala fortuna venga fuora questa opera, che l'habbia da venire in mano di lettori cosi rozi, \& inetti, che questo credino." 
that this is not a case of casting the pearls of knowledge "before swine," as a certain kind of culture that claimed lordship over knowledge presumed; on the contrary, it is a matter of supplying - pro bono publico - a vast public that wants to be educated with the knowledge and the means to achieve cultural emancipation, not only for the sake of progress but also for the purpose of ethical and moral edification. ${ }^{149}$ This is why the relationship between vernacular Aristotelianism and the people is an important chapter in the intellectual history of the Renaissance.

149. On this period of transition, see William Eamon, Science and the Secrets of Nature: Books of Secrets in Medieval and Early Modern Culture (Princeton: Princeton University Press, 1994), 319-50; Rossi, Il tempo dei maghi, 275-304. 